archives-ouvertes

\title{
From 2-to 3-Substituted Ferrocene Carboxamides or How to Apply Halogen "Dance" to the Ferrocene Series
}

Mehdi Tazi, William Erb, Yury S. Halauko, Oleg A. Ivashkevich, Vadim E. Matulis, Thierry Roisnel, Vincent Dorcet, Florence Mongin

\section{To cite this version:}

Mehdi Tazi, William Erb, Yury S. Halauko, Oleg A. Ivashkevich, Vadim E. Matulis, et al.. From 2-to 3-Substituted Ferrocene Carboxamides or How to Apply Halogen "Dance" to the Ferrocene Series. Organometallics, American Chemical Society, 2017, 36 (24), pp.4770-4778. 10.1021/acs.organomet.7b00659 . hal-01685699

HAL Id: hal-01685699

https://hal-univ-rennes1.archives-ouvertes.fr/hal-01685699

Submitted on 20 Apr 2018

HAL is a multi-disciplinary open access archive for the deposit and dissemination of scientific research documents, whether they are published or not. The documents may come from teaching and research institutions in France or abroad, or from public or private research centers.
L'archive ouverte pluridisciplinaire HAL, est destinée au dépôt et à la diffusion de documents scientifiques de niveau recherche, publiés ou non, émanant des établissements d'enseignement et de recherche français ou étrangers, des laboratoires publics ou privés. 


\title{
From 2- to 3-Substituted Ferrocene Carboxamides or How to Apply Halogen 'dance' to the Ferrocene Series
}

\author{
Mehdi Tazi,${ }^{\dagger}$ William Erb, ${ }^{*} \dagger$ Yury S. Halauko, ${ }^{*} *$ Oleg A. Ivashkevich, ${ }^{\dagger}$ Vadim E. Matulis,${ }^{\S}$ \\ Thierry Roisnel, ${ }^{\mathbb{I}}$ Vincent Dorcet ${ }^{\mathrm{Il}}$ and Florence Mongin ${ }^{\dagger}$ \\ ${ }^{\dagger}$ Equipe Chimie Organique et Interfaces, Institut des Sciences Chimiques de Rennes, UMR 6226 CNRS-Université de \\ Rennes 1, Bâtiment 10A, Case 1003, Campus Scientifique de Beaulieu, 35042 Rennes Cedex, France \\ * UNESCO Chair of Belarusian State University, 14 Leningradskaya Str., Minsk 220030, Belarus \\ $\S$ Research Institute for Physico-Chemical Problems of Belarusian State University, 14 Leningradskaya Str., Minsk 220030, \\ Belarus \\ "I Centre de Diffractométrie X, Institut des Sciences Chimiques de Rennes, UMR 6226 CNRS-Université de Rennes 1, Bâti- \\ ment 10B, Campus de Beaulieu, 35042 Rennes Cedex, France
}

Supporting Information Placeholder

\begin{abstract}
Two methods were compared to convert ferrocene into $N, N$-diisopropylferrocenecarboxamide, $N, N$-diethylferrocenecarboxamide, $\mathrm{N}, \mathrm{N}$-dimethylferrocenecarboxamide and (4-morpholinocarbonyl)ferrocene, namely deprotometalation followed by trapping using dialkylcarbamoyl chlorides and amide formation from the intermediate carboxylic acid. The four ferrocenecarboxamides were functionalized at $\mathrm{C}^{2}$; in the case of the less hindered and more sensitive amides, recourse to a mixed lithium-zinc 2,2,6,6-tetramethylpiperidinobased base allowed to achieve the reactions. Halogen migration using lithium amides was next optimized. Whereas it appeared impossible to isolate the less hindered 3-iodoferrocenecarboxamides, 3 -iodo- $N, N$-diisopropylferrocenecarboxamide proved stable and was converted to new 1,3-disubstituted ferrocenes by Suzuki coupling or amide reduction. DFT calculations were used to rationalize the results obtained.
\end{abstract}

\section{INTRODUCTION}

Polysubstituted ferrocenes are much appreciated scaffolds for various applications including catalysis, fuel additives, material sciences and medicinal chemistry. ${ }^{1}$

Methods to access 1,2-disubstituted ferrocenes have been largely developed from monosubstituted ferrocenes. ${ }^{2}$ Among the methods used, deprotonative lithiations directed at neighboring sites by coordinating or/and acidifying groups are of crucial importance. Ferrocenecarboxylic acid derivatives such as hindered $N, N$-dialkylcarboxamides ${ }^{3}$ and oxazolines ${ }^{2 b, 4}$ have been often employed to this purpose, with stereoselective reactions being possible by using chiral ligands or chiral directing groups, respectively.

In sharp contrast, if 1,3-disubstituted ferrocenes appear as promising for different applications, ${ }^{5}$ their synthesis is far less developed. Obtaining such structures by building the ferrocene core $^{6}$ is possible but subjected to tedious preparation of the required substrates. Thus, access by functionalization of ferrocene is an attractive approach. From monosubstituted ferrocenes, direct electrophilic substitutions are hardly regioselective. ${ }^{7}$ Stoichiometric and catalytic $\mathrm{CH}$-functionalizations can take place at positions remote from substituents, but these reactions are limited to specific groups ${ }^{8}$ or bases, ${ }^{9}$ and can hardly be made stereoselective. Alternative ways to access 1,3-disubstituted ferrocenes consist in using retractable directing groups. Chlorine, ${ }^{10}$ bromine $^{11}$ and sulfoxide $^{12}$ have been successfully used to this purpose, and enantiopure derivatives could be obtained. ${ }^{12,11 \mathrm{e}}$
Base-catalyzed aromatic halogen 'dance' is an elegant way to convert 2-halogeno substituted benzenes ( $\mathrm{I}>\mathrm{Br}$ ) into the corresponding 3-substituted derivatives. ${ }^{13}$ Relatively well-developed in the benzene series, the reaction has been subjected to very few studies from ferrocenes. In 2010, we reported the competitive formation of 1-bromo-3-iodoferrocene in the course of the deprotometalation-iodolysis of bromoferrocene using the base in situ prepared from $\mathrm{ZnCl}_{2}$. TMEDA (TMEDA $=N, N, N$ ', $N$ 'tetramethylethylenediamine) and LiTMP (TMP $=2,2,6,6-$ tetramethylpiperidino) in a $1: 3$ ratio, ${ }^{14}$ and supposed to be a $1: 1$ mixture of LiTMP and $\mathrm{Zn}(\mathrm{TMP}) 2 .{ }^{15}$ More recently, Wang, Weissensteiner and co-workers showed that the reactions performed on ferrocenyl 1,2-dihalides (1-chloro-2-iodo-, 1-bromo-2-iodo-, 1,2dibromo- and 1,2-diiodoferrocene) using LiTMP more look like a 'scrambling' than a 'dance', with complex mixtures obtained. ${ }^{16}$

We thought a way to reduce this complexity was to involve in such reactions 1,2-disubstituted ferrocenes bearing only one halogen and a fixed $N, N$-dialkylcarboxamide directing group. We thus chose 2-iodoferrocenecarboxamides to attempt base-catalyzed halogen migration. Herein, we describe our efforts to efficiently synthesize the required substrates and to convert them into the corresponding 3-iodoferrocenecarboxamides. The molecular structure of the above mentioned ferrocenes was studied by ${ }^{1} \mathrm{H}$ and ${ }^{13} \mathrm{C}$ NMR spectroscopy, and DFT calculations were used to rationalize the results. 


\section{RESULTS AND DISCUSSION}

Compared methods to access $N, N$-dialkyl ferrocenecarboxamides. $N, N$-dialkyl ferrocenecarboxamides are important substrates for subsequent elaboration. Therefore, we planned the synthesis of four ferrocenecarboxamides, namely the $\mathrm{N}, \mathrm{N}$ diisopropyl, $N, N$-diethyl, $N, N$-dimethyl and morpholino. Direct reaction of ferrocene with dialkylcarbamoyl chlorides was reported to give the corresponding carboxamides in moderate yields. ${ }^{17}$ In our hands, reacting ferrocene with diethylcarbamoyl chloride in the presence of $\mathrm{AlCl}_{3}$ (1.1 equiv) at dichloromethane reflux provided $N, N$-diethylferrocenecarboxamide in $33 \%$ yield $(5 \%$ yield by using 2 equiv of $\mathrm{AlCl}_{3}$; no product and $66 \%$ recovered ferrocene by employing 1.1 equiv of $\mathrm{SnCl}_{4}$ ). This disappointing yield led us to consider alternative syntheses.

We considered and evaluated two routes toward these substrates: ferrocene deprotometalation followed by trapping using dialkylcarbamoyl chlorides (Route $A)^{18}$ and amide formation from ferrocenecarboxylic acid ${ }^{19}$ (Route $\left.B\right){ }^{20}$ As shown in Table 1, the two routes work in similar yields although Route A provides the ferrocenecarboxamides 1-4 in only one step from cheap ferrocene. All the products obtained were fully characterized, and their main spectroscopic and X-ray diffraction data are furnished in Supporting Information.

Deprotometalation to afford $\mathbf{N}, \mathbf{N}$-dialkyl 2iodoferrocenecarboxamides (Table 2). $N, N$-diisopropyl- and $N, N$-diethylferrocenecarboxamide (1 and 2) can be deprotolithiated by butyllithium in $\mathrm{Et}_{2} \mathrm{O}$ at $-80{ }^{\circ} \mathrm{C}$. ${ }^{3 \mathrm{a}, \mathrm{b}}$ From $\mathbf{1}$, using the chelate BuLi-TMEDA followed by iodolysis led to the expected iodide $\mathbf{5}^{21}$ in $88 \%$ yield. Alternatively, employing at room temperature the base in situ prepared from $\mathrm{ZnCl}_{2}$. TMEDA (0.5 equiv) and LiTMP (1.5 equiv) ${ }^{14}$ (supposed to be a 1:1 mixture of LiTMP and $\left.\mathrm{Zn}(\mathrm{TMP})_{2}\right)^{15}$ furnished 5 in $84 \%$ yield. From 2, we preferred the latter method, and isolated the 2-iodo derivative $\mathbf{6}$ in $88 \%$ yield.

When compared to $\mathbf{1}$ and $\mathbf{2}, N, N$-dimethylferrocenecarboxamide (3) and morpholinoferrocenecarboxamide (4) are more sensitive to nucleophilic attacks. Consequently, ketones are concomitantly formed upon their treatment by organolithiums, and lower yields of 2-substituted derivatives are noticed after subsequent quenching. Recourse to LiTMP with in situ trapping (e.g. $\mathrm{ClSiMe}_{3}$ ) makes functionalization of such substrates possible. ${ }^{22}$ Although iodine cannot be used as in situ trap, the zinc species formed next to the directing group by deprotolithiation-"trans-metal trapping, ${ }^{23}$ using the combination of LiTMP ( 0.5 equiv) and $\mathrm{Zn}(\mathrm{TMP})_{2}$ ( 0.5 equiv) can be converted to the corresponding iodides $\mathbf{7}$ and $\mathbf{8}$ which were isolated in 78 and $84 \%$ yield, respectively. The main spectroscopic and X-ray diffraction data are given in Supporting Information and/or Figure 1.

Halogen 'dance' to afford $N, N$-dialkyl 3-iodoferrocenecarboxamides. Deprotonation-triggered heavy halogen migration $^{13}$ appeared to be a suitable approach for the conversion of 1-substituted 2-iodoferrocenes into their 1-substituted 3-iodo isomers. ${ }^{14,16} \mathrm{~A} \mathrm{~N}, \mathrm{~N}$-dialkylcarboxamide being capable of coordinating lithium when located at a neighboring position on a ring, it can contribute to the stabilization of a lithio compound and thus direct halogen migration. To the best of our knowledge, such a group has only been used to direct halogen migration in the case of 3-iodo- $N, N$-diisopropyl-2pyridinecarboxamide (Chart 1 , left).$^{24}$ According to the generally accepted mechanism, ${ }^{13}$ the reaction promoted by a lithium amide $(\mathrm{LiDA}=$ lithium diisopropylamide) proceeds through deprotonation at the 4 position and repetitive halogen/metal exchanges.

Table 1. Formation of the $N, N$-dialkyl ferrocenecarboxamides 1-4 using Route $A$ and Route $B$.

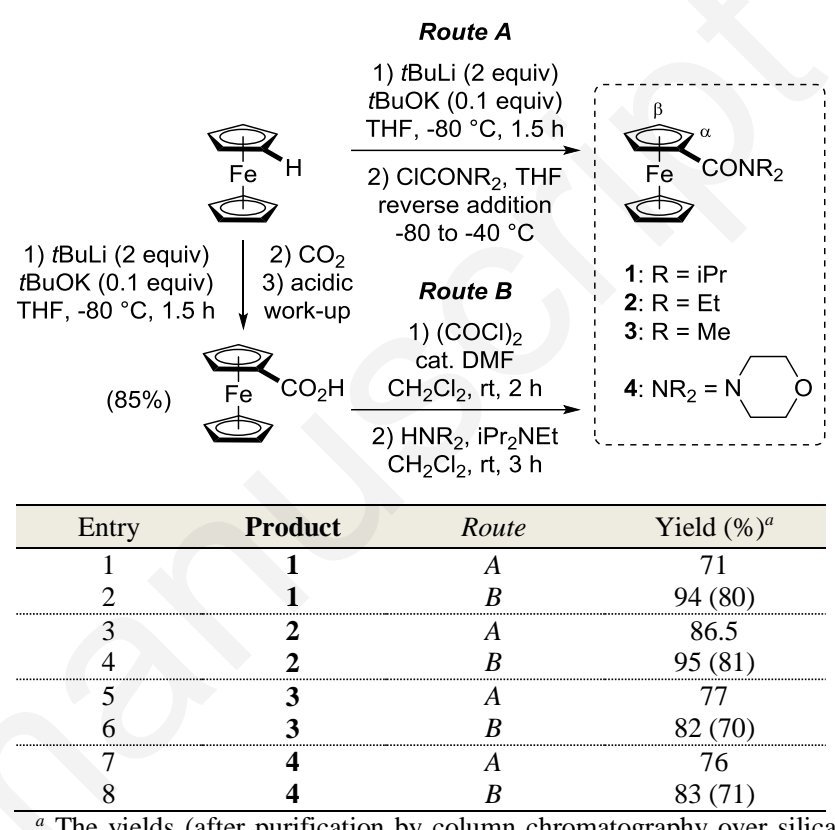
gel) for Route $A$ and $B$ were calculated from ferrocene and ferrocenecarboxylic acid, respectively. The yields in parentheses are calculated from ferrocene.

Table 2. Formation of the $N, N$-dialkyl 2-iodoferrocenecarboxamides 5-8.

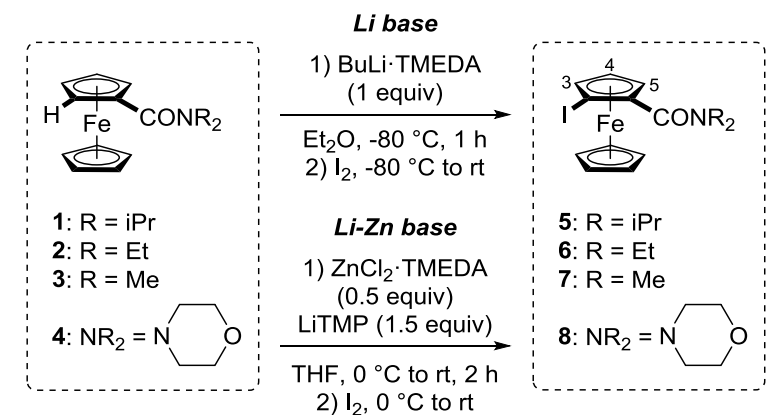

\begin{tabular}{|c|c|c|c|}
\hline Entry & Product & Base & Yield $(\%)^{a}$ \\
\hline 1 & 5 & $L i$ & 88 \\
\hline 2 & 5 & $L i-Z n$ & 84 \\
\hline 3 & 6 & $L i-Z n$ & 88 \\
\hline 4 & 7 & $\mathrm{Li}-\mathrm{Zn}$ & 78 \\
\hline 5 & 8 & $L i-Z n$ & 84 \\
\hline
\end{tabular}

${ }^{a}$ Yields after purification by column chromatography over silica gel.

Beside different electronic and geometrical features (e.g. angles), the position next to the carboxamide is locked by the pyridine nitrogen in the reported example whereas it can be 
attacked by a base in the case of the ferrocenecarboxamides 5 8 (Chart 1). Although silyl protection is possible, we did not consider this strategy as studies showed that hindered ferrocene carboxamides ${ }^{22}$ bearing such silanes at $\mathrm{C}^{2}$ can hardly be deprotonated at $\mathrm{C}^{5}$, but rather on the unsubstituted $\mathrm{Cp}$ ring. Carboxamide orientation seems to impact the metalation efficiency, the reaction being favored when the $\mathrm{C}=\mathrm{O}$ group is in the plane of the substituted $\mathrm{Cp}$ ring. ${ }^{25}$

Chart 1. Substrate on which a carboxamide has been used to direct halogen migration (left) and planned substrates to attempt ferrocene halogen 'dance' (right).
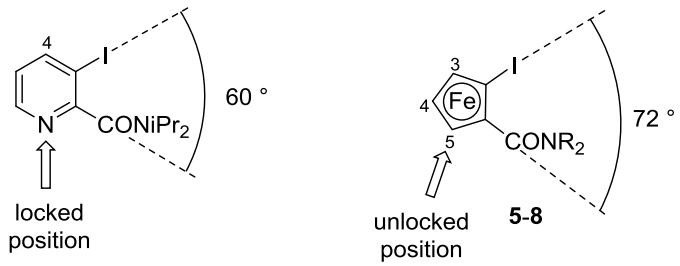

Different aspects of the molecular structure of ferrocenes and their derived properties were studied by quantum chemical calculations. ${ }^{26}$ It is established that ferrocenes can exist as eclipsed and staggered conformations with a low internal rotation barrier. ${ }^{27}$ In our case (see Supporting Information), the investigated ferrocenes are predominantly in an eclipsed form with hydrogens slightly bent inward. We considered the carboxamide conformation space next.

Due to the presence of the heavy halogen at $\mathrm{C}^{2}$ in $\mathbf{5}$, as in the case of silyl-protected carboxamide, the favored conformation seems to have the carboxamide $\mathrm{C}=\mathrm{O}$ out of the $\mathrm{Cp}$ plane (even nearly perpendicular, see Figure 1), and thus not suitable to induce metalation at $\mathrm{C}^{5}$. We thus tried to assess, for $\mathbf{1}$ and 5, the energy difference between the most stable conformation and the conformation with coplanar $\mathrm{C}=\mathrm{O}$ and $\mathrm{Cp}$ ring. Because we could not get this information by using dynamic NMR studies (see Supporting Information), we calculated their energy profiles upon rotation around their $\mathrm{C}^{1}-\mathrm{C}=\mathrm{O}$ bond (Figure 2). It was found earlier ${ }^{28}$ that for ferrocene carboxamides the bulkier the substituent is, the greater the value of angle between the $\mathrm{Cp}$ and amide planes is.

Whereas the computed conformations of lowest energy are very close to the structures obtained by X-ray diffraction, a local maximum $(+24 \mathrm{~kJ} / \mathrm{mol})$ is noticed for the conformation of 1 with the $\mathrm{C}=\mathrm{O}$ group in the plane of the $\mathrm{Cp}$ (Figure 2, top), and two maxima (local at +30 and global at $+50 \mathrm{~kJ} / \mathrm{mol}$ ) were recorded for the two 'in-plane' conformers of 5 (Figure 2, bottom; respectively $0^{\circ}$ in the case of the $\mathrm{C}=\mathrm{O}$ group on the iodine side (syn) and $180^{\circ}$ for the $\mathrm{C}=\mathrm{O}$ group on the opposite side (anti)). ${ }^{28}$ This large value led us to suppose that the $\mathrm{C}=\mathrm{O}$ group can hardly stabilize a 2-iodo-5-lithio-ferrocenecarboxamide by lithium coordination, and we were confident that halogen migration will take place without protective group.

We decided to optimize the reaction on 2 -iodo- $N, N$ diisopropylferrocenecarboxamide (5) and to next apply the best conditions to the other $N, N$-dialkyl-2-iodoferrocenecarboxamides $\mathbf{6}, 7$ and $\mathbf{8}$. On the basis of the mechanism proposed in Scheme 1, we considered LiTMP as a better lithium amide than LiDA. ${ }^{29}$ Indeed, 2,2,6,6-tetramethylpiperidine $(\mathrm{H}$ TMP; $\left.\mathrm{p} K_{\mathrm{a}}=37.3\right)^{30}$ is less prone to protonate 2-lithio- $N, N$ - diisopropylferrocenecarboxamide than diisopropylamine $\left(\mathrm{p} K_{\mathrm{a}}\right.$ $=35.7){ }^{30}$
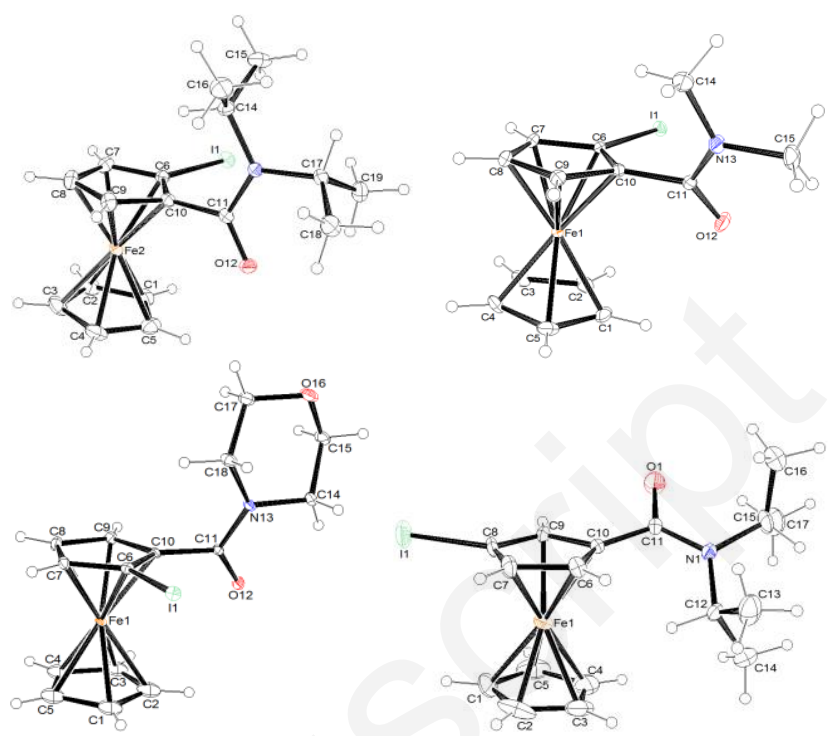

Figure 1. ORTEP diagrams $(30 \%$ probability level) of the ferrocenecarboxamides $5\left(\mathrm{C}^{9}-\mathrm{C}^{10}-\mathrm{C}^{11}-\mathrm{O}^{12}\right.$ torsion angle: 94.36 $\left.{ }^{\circ}\right), 7\left(C^{9}-C^{10}-C^{11}-O^{12}: 121.02^{\circ}\right), 8\left(C^{9}-C^{10}-C^{11}-O^{12}\right.$ : $\left.70.86^{\circ}\right)$ and $9\left(C^{9}-C^{10}-C^{11}-O^{1}: 27.01^{\circ}\right)$.
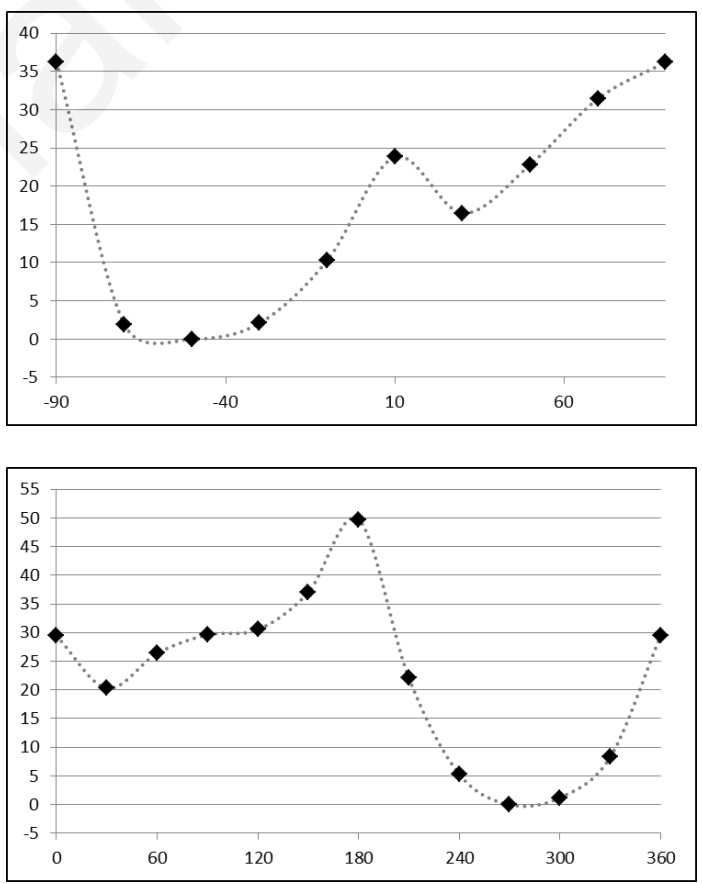

Figure 2. Energy profiles (kJ/mol) of 1 (top) and 5 (bottom) upon torsion angle $\left({ }^{\circ}\right) \mathrm{C}^{2}-\mathrm{C}^{1}-\mathrm{C}=\mathrm{O}$ change.

Thus, we treated the 2-iodoferrocenecarboxamide 5 by LiTMP (1.1 equiv) in THF (THF = tetrahydrofuran) for $2 \mathrm{~h}$ at different reaction temperatures (from -30 to $-80{ }^{\circ} \mathrm{C}$ ) before subsequent hydrolysis. In all these experiments, we observed (gas chromatography (GC) mass spectrometry) the formation of 3-iodo- $N, N$-diisopropylferrocenecarboxamide (9) as well as the deiodinated compound $\mathbf{1}$ in addition to the recovered start- 
ing material 5. Whereas $-30{ }^{\circ} \mathrm{C}$ favored deiodination $(\mathbf{1}$ formed in $\sim 40 \%$ estimated yield), starting material $\mathbf{5}$ was importantly recovered at $-80{ }^{\circ} \mathrm{C}(\sim 55 \%$ estimated yield $)$. Regarding the expected isomerized iodide $\mathbf{9}$, its formation was favored at -50 ${ }^{\circ} \mathrm{C}$. Other mono- and diiodides were formed, but in general as minority products.

Consequently, we kept $-50{ }^{\circ} \mathrm{C}$, and checked different reaction times $(5 \mathrm{~min}, 15 \mathrm{~min}, 30 \mathrm{~min}, 6 \mathrm{~h}, 14 \mathrm{~h}$ and $20 \mathrm{~h}$; see Supporting Information). The results show that the 2lithioferrocenecarboxamide is rapidly formed (giving $\mathbf{1}$ by hydrolysis), but the conversion to the 3-iodo-2-lithio derivative (affording 9 by hydrolysis) takes more time. Once the starting 5 exhausted $(\sim 14 \mathrm{~h})$, there is no benefit to use longer reaction times.

Scheme 1. Proposed mechanism for halogen 'dance' on 2iodoferrocenecarboxamides.

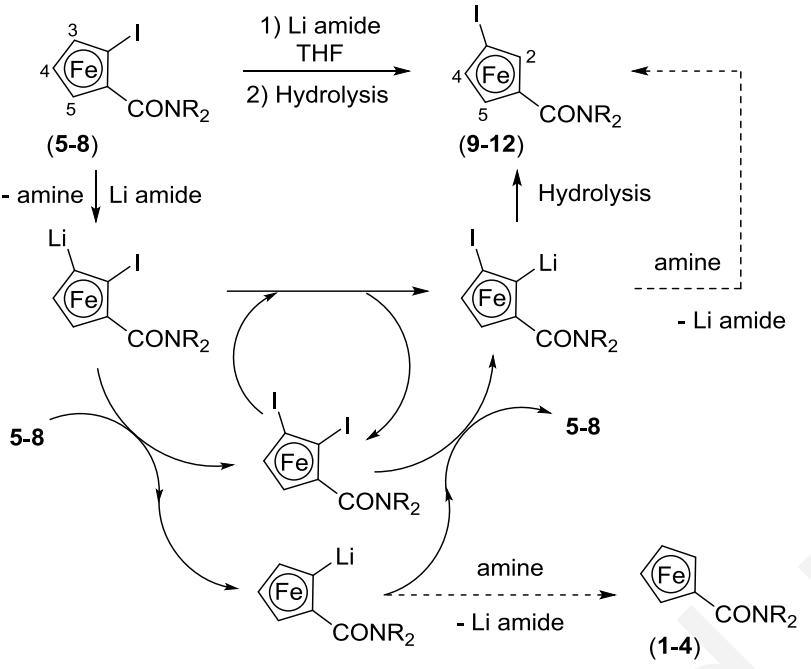

Under the optimized reaction conditions, LiTMP proved superior to LiDA, often employed as halogen 'dance' mediator. ${ }^{13}$ With LiDA, extending the reaction time favored the deiodinated product 1 to the detriment of the expected 3-iodoferrocenecarboxamide 9 (see Supporting Information). These results, that could be due to the higher propensity of diisopropylamine to protonate the 2-lithioferrocenecarboxamide when compared with LiTMP, led us to abandon LiDA.

These optimized conditions (1.1 equiv of LiTMP, THF, -50 ${ }^{\circ} \mathrm{C}, 14 \mathrm{~h}$ ) in hand, we studied the behavior of the less hindered 2-iodoferrocenecarboxamides 6-8 in the reaction. For more sensitive 2-iodo- $N, N$-dimethylferrocenecarboxamide (7), the estimated yield of the 3 -iodo product $\mathbf{1 1}$ was improved at a lower temperature. From $\mathrm{N}, \mathrm{N}$-diethyl-2-iodoferrocenecarboxamide (6) and 1-iodo-2-(4-morpholino-carbonyl)ferrocene $(\mathbf{8})$, conducting the reaction at a larger scale $(4.0$ mmol instead of 1.0) provided the respective 3-iodo derivatives $\mathbf{1 0}$ and 12 more efficiently (see Supporting Information).

One main issue of the approach is to isolate the isomerized products 9-12. Unlike the $N, N$-diisopropylferrocenecarboxamide 9, separable from the deiodinated compound $\mathbf{1}$ and the other iodides by column chromatography over silica gel (36\% yield at a $1.0 \mathrm{mmol}$ scale; $53 \%$ yield at a $4.0 \mathrm{mmol}$ scale), the less hindered $N, N$-dialkyl ferrocenecarboxamides 10-12 proved much less stable. The $N, N$-diethylcarboxamide 10 could be purified by column chromatography over silica gel (32\% yield at a $1.0 \mathrm{mmol}$ scale), but in a non-reproducible way. Even worse, the $N, N$-dimethylcarboxamide $\mathbf{1 1}$ and the morpholino-based carboxamide $\mathbf{1 2}$ were never isolated. As a consequence, crystals suitable for X-ray diffraction were only obtained for the 3-iodo derivative 9 (Figure 1).

To understand why deiodination competes, we treated the ferrocenecarboxamide 1 by LiTMP (1.1 equiv) in THF at -50 ${ }^{\circ} \mathrm{C}$ for $6 \mathrm{~h}$. After subsequent iodolysis, we isolated the 2-iodo derivative $\mathbf{5}$ in a low $7 \%$ yield. Similarly, iodolysis of the halogen 'dance' reaction mixture after $6 \mathrm{~h}$ at $-50{ }^{\circ} \mathrm{C}$ produces much more 1 ( $~ 60 \%$ yield) than 2-lithioferrocenecarboxamide $(\sim 10 \%)$. That the latter easily reacts with H-TMP could explain why 1 first and easily accumulates in the reaction mixture before disappearing. In order to reduce such a protonation, we tried to use 2 equiv of LiTMP. Unfortunately, the formation of $\mathbf{9}$ is not favored under these conditions. By decreasing the amount of lithium amide to 0.5 equiv, the halogen 'dance' is considerably prevented with $\mathbf{5}$ remaining present in $\sim 30 \%$ yield and deiodination similarly taking place (see Supporting Information).

Last but not least, as $N, N$-diisopropyl-2-lithioferrocenecarboxamide, 3-iodo- $N, N$-diisopropyl-2-lithioferrocenecarboxamide is prone to in situ protonation by H-TMP. Indeed, trapping by electrophiles $\left(\mathrm{PhCHO}, \mathrm{PhSSPh}, \mathrm{ClPPh}_{2}\right)$ the halogen 'dance' reaction mixture led to complex mixtures while using $\mathrm{DCl}-\mathrm{D}_{2} \mathrm{O}$ only allowed 2-deuterio-3-iodo- $N, N$-diisopropylferrocenecarboxamide to be isolated as a 1:1 mixture $(\sim 30 \%$ yield) with 9.

In most cases, the deiodination is accompanied by formation of unwanted unstable mono- and diiodides. Because we could not isolate any of the side products, we tried to get information from the NMR spectra of fractions containing them. First, we completely assigned the ${ }^{1} \mathrm{H}$ and ${ }^{13} \mathrm{C}$ NMR signals of $\mathbf{1 ,} 5$ and $\mathbf{9}$, and deduced the NMR increments of both the $\mathrm{CONiPr}_{2}$ and iodo substituents (see Supporting Information).

In several experiments (notably by using an excess of base to attempt the reaction), we observed the formation $(<10 \%$ yield estimated by GC mass spectrometry) of an isomer of $\mathbf{5}$ and 9. This compound was identified as being 1'-iodo- $N, N$ diisopropylferrocenecarboxamide by NMR and GC comparison with the product resulting from silyl deprotection of 1'iodo- $N, N$-diisopropyl-2-(trimethylsilyl)ferrocenecarboxamide.

Concerning the diiodides, we could get information from the ${ }^{13} \mathrm{C}$ NMR spectra of fractions containing them. In particular, the chemical shift of the $\mathrm{C}^{1}$ carbon (connected to $\mathrm{C}=\mathrm{O}$ ) largely depends on the presence of iodine atoms at $\mathrm{C}^{2}$ and $\mathrm{C}^{5}$. Indeed, at $81.3 \mathrm{ppm}$ in the absence of neighboring iodine (compound 1), this signal moves to $92.6 \mathrm{ppm}$ in the presence of iodine at $\mathrm{C}^{2}$ (compound 5), but is not modified significantly with iodine at $C^{3}\left(82.8 \mathrm{ppm}\right.$, compound 9). Thus, with a $\mathrm{C}^{1}$ at $97.2 \mathrm{ppm}$, we are inclined to think that the diiodide most often formed in our halogen 'dance'-hydrolysis sequences is the 2,5diiodocarboxamide. After halogen 'dance'-iodolysis, a new diiodide is formed (longer retention time on GC mass spectrometry); we supposed it is the 2,3-diiodocarboxamide shown in Scheme 1, formed by iodolysis of the 3-iodo-2-lithioferrocenecarboxamide. Nevertheless, this second diiodide is rarely observed in our halogen 'dance'-hydrolysis reactions; 
instead, in addition to the 2,5-diiodocarboxamide, a third diiodide is often noticed. We have no clue to identify it, but the 2,4-diiodo derivative could be a possible candidate. This NMR study at least seems to show that deprotometalation of $\mathbf{5}$ lacks of regioselectivity (next to iodine $v s$. carboxamide).

To get more information on these diiodides, we attempted the use of the base in situ prepared from $\mathrm{ZnCl}_{2}$. TMEDA $(0.5$ equiv) and LiTMP (1.5 equiv) ${ }^{14}$ to prepare diiodides from the iodocarboxamide 5. Under the conditions used in Table 2, the preponderant formation of 2,5-diiodinated ferrocenecarboxamides was suspected on the basis of the ${ }^{13} \mathrm{C}$ NMR data of the mixture obtained (peaks at 97.2 and $98.1 \mathrm{ppm}$ for the main polyiodides formed). This evidences a favored kinetic deprotometalation of $\mathbf{5}$ next to the carboxamide function.

All these observations led us to consider the results in the light of the $\mathrm{p} K_{\mathrm{a}}$ values of key ferrocene derivatives. In 1973, Denisovich and Gubin described ferrocene as being more acidic than benzene, with a $\mathrm{p} K_{\mathrm{a}}$ value of $39 \pm 3$ in MSAD scale (polarography). ${ }^{31}$ To our knowledge, this represents the only ferrocene $\mathrm{p} K_{\mathrm{a}}$ determination. Thus, we calculated the $\mathrm{CH}$ acidity ( $\mathrm{p} K_{\mathrm{a}}$ values) in THF solution of Fc-H, Fc-I, 1, 5 and 9 within the DFT framework by using the approach elaborated earlier $^{32}$ (Chart 2). Whereas iodine exerts its known short- and long-range acidifying effects, the carboxamide function as such acidifies more moderately. When coordinated to lithium (calculations performed by using LiF), the carboxamide becomes a stronger directing group, as shown in Chart 3.

Upon carboxamide coordination to lithium, the 1' position of ferrocene $\mathbf{5}$ is greatly acidified and amenable to deprotonation; this might explain why 1 '-iodo- $N, N$-diisopropylferrocenecarboxamide is observed in experiments. Besides, when compared to the site next to iodine, the position adjacent to the carboxamide is somewhat more activated; this could explain why deprotonation competitively takes place at $\mathrm{C}^{5}$, as demonstrated by 2,5-diiodocarboxamide formation.

Once coordinated to the metal, the $\mathrm{C}^{2}$ position of the 3 iodoferrocenecarboxamide $\mathbf{9}$ is highly activated; this allows to explain why the equilibria between the different lithioferrocenes are shifted toward the expected 3-iodo-2-lithioferrocenecarboxamide.

The reason why reaction times exceeding $14 \mathrm{~h}$ are not suitable to reach high yields could be due to LiTMP destruction, ${ }^{33}$ favoring 2-lithioferrocenecarboxamide reprotonation. Competitive iodine/lithium exchange by $\mathrm{LiTMP}^{34}$ could also be advanced to rationalize the iodine loss observed all along the reaction.

In order to obtain new kinds of ferrocenes, we made derivatives from the 3-iodoferrocenecarboxamide 9 (Scheme 2). Using 4-methoxyphenyl- and 4-(trifluoromethyl)phenylboronic acid in the presence of cesium fluoride, ${ }^{35}$ and catalytic amounts of $\operatorname{Pd}(\mathrm{dba})_{2}(\mathrm{dba}=$ dibenzylideneacetone $)$ and triphenylphosphine, at the reflux temperature of toluene, ${ }^{36}$ respectively afforded the Suzuki coupling products 13 and 14 in moderate yields. The $N, N$-diisopropylaminomethylferrocene $\mathbf{1 5}$ was in turn prepared by reduction of the carboxamide function using $\mathrm{BH}_{3}$. THF, as documented previously. ${ }^{3 \mathrm{a}}$
Chart 2. Selected calculated $\mathrm{p} K \mathrm{a}$ values in THF solution for Fc-H, Fc-I, 1, 5 and 9 (top and middle: most stable conformation; bottom: $C p$ and $C=O$ coplanar $-9^{2}$ and $9^{5}$ with the $\mathrm{C}=\mathrm{O}$ group respectively pointing toward $\mathrm{C}^{2}$ and $\mathrm{C}^{5}$ ).

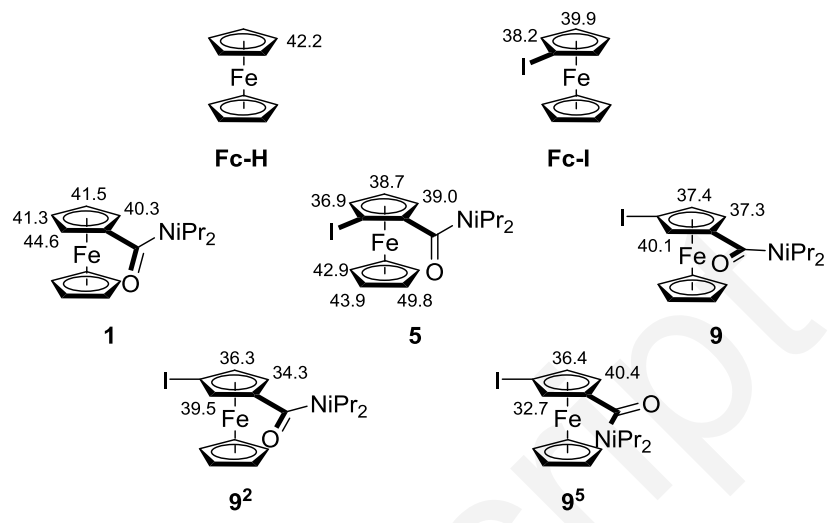

Chart 3. Selected calculated $p K_{\mathrm{a}}$ values in THF solution for $5 \cdot \mathrm{LiF}$ (most stable conformation of 5 ) and $9 \cdot \mathrm{LiF}(\mathrm{Cp}$ and $\mathrm{C}=\mathrm{O}$ coplanar).

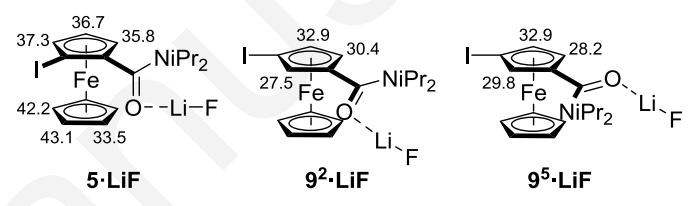

We have thus shown that it is possible to access 1,3disubstituted ferrocenes, which are promising substrates for different applications, ${ }^{5}$ with recourse to halogen 'dance'.

\section{CONCLUSION}

We studied the halogen 'dance' reaction from different $N, N$ dialkyl 2-iodoferrocenecarboxamides. In spite of the low stability of the less hindered 3-iodoferrocenecarboxamides, we could optimize the reaction giving 3-iodo- $\mathrm{N}, \mathrm{N}$-diisopropylferrocenecarboxamide (9) and identify possible reasons at the origin of the side products formation.

One limit encountered in this halogen 'dance' is the formation of undesirable diiodides, notably due to the relatively high acidity found at $\mathrm{C}^{5}$ on 2-iodo- $N, N$-diisopropylferrocenecarboxamide (5). By using deuterium to protect this position toward deprotonation, ${ }^{4 \mathrm{~b}}$ one could favor the formation of the expected 3-iodo-2-lithioferrocenecarboxamide.

Competitive deiodination and lithioferrocene reprotonation proved to be main issues of the reaction. We will devote efforts in order to identify ferrocene substituents capable of making the generated ferrocenyllithiums more stable toward H-TMP. 
Scheme 2. Conversion of 9 by Suzuki coupling and carboxamide reduction.
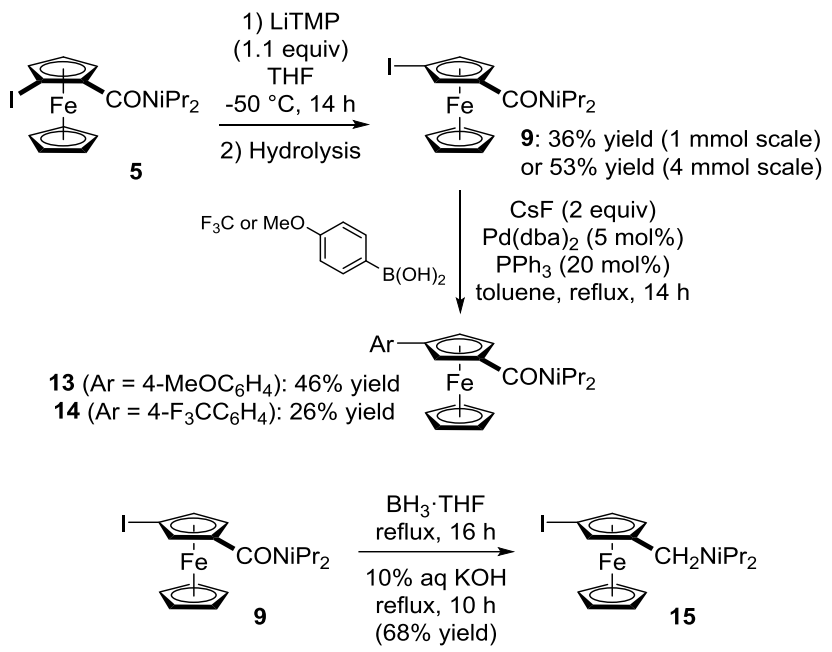

\section{EXPERIMENTAL SECTION}

General Details. All the reactions were performed under an argon atmosphere using standard Schlenk techniques. THF was distilled over sodium/benzophenone. Column chromatography separations were achieved on silica gel $(40-63 \mu \mathrm{m})$. Melting points were measured on a Kofler apparatus. IR spectra were taken on a Perkin-Elmer Spectrum 100 spectrometer. ${ }^{1} \mathrm{H}$ and ${ }^{13} \mathrm{C}$ Nuclear Magnetic Resonance (NMR) spectra were recorded either (i) on a Bruker Avance III spectrometer at $300 \mathrm{MHz}$ and $75 \mathrm{MHz}$, respectively, or/and (ii) on a Bruker Avance III $\mathrm{HD}$ at $500 \mathrm{MHz}$ and $126 \mathrm{MHz}$, respectively. ${ }^{1} \mathrm{H}$ chemical shifts $(\delta)$ are given in ppm relative to the solvent residual peak and ${ }^{13} \mathrm{C}$ chemical shifts are relative to the central peak of the solvent signal. ${ }^{37}$ Ferrocenecarboxylic acid is commercially available, but can be easily prepared according to a previously reported procedure. ${ }^{19}$

For 2-4, 6-9 and 13, the X-ray diffraction data were collected using D8 VENTURE Bruker AXS diffractometer at the temperature given in the crystal data. The samples were studied with monochromatized Mo-K $\alpha$ radiation $(\lambda=0.71073 \AA)$. The structure was solved by dualspace algorithm using the SHELXT program, ${ }^{38}$ and then refined with full-matrix least-square methods based on $F^{2}$ (SHELXL) ${ }^{39}$ All nonhydrogen atoms were refined with anisotropic atomic displacement parameters. $\mathrm{H}$ atoms were finally included in their calculated positions. The molecular diagrams were generated by ORTEP-3 (version 2.02). ${ }^{40}$

General procedure 1 (Route $A$ ). The protocol was adapted from a previously reported procedure. ${ }^{41}$ To a stirred mixture of ferrocene $(0.93 \mathrm{~g}, 5.0 \mathrm{mmol})$ and ${ }^{\mathrm{t}} \mathrm{BuOK}(56 \mathrm{mg}, 0.5 \mathrm{mmol})$ in THF $(45 \mathrm{~mL})$ at $-80{ }^{\circ} \mathrm{C}$, was added dropwise ${ }^{\mathrm{t}} \mathrm{BuLi}(\sim 1.9 \mathrm{M}$ in pentane, $10 \mathrm{mmol})$. After $1.5 \mathrm{~h}$ at this temperature, the mixture was rapidly transferred dropwise through a cannula to a solution of the required dialkyl carbamoyl chloride (the amount is given in the product description) in THF $(15 \mathrm{~mL})$ at $-80{ }^{\circ} \mathrm{C}$, and the resulting mixture was allowed to warm to $-40{ }^{\circ} \mathrm{C}$ before quenching by an aqueous saturated solution of $\mathrm{NH}_{4} \mathrm{Cl}(50 \mathrm{~mL})$. Extraction with AcOEt $(3 \times 20 \mathrm{~mL})$, washing with brine $(20 \mathrm{~mL})$, drying over $\mathrm{MgSO}_{4}$, removal of the solvents and purification by chromatography on silica gel (the eluent is given in the product description) led to the expected compound (see Supporting Information for experimental data on the compounds 2-4).

General procedure 2 (Route B) ${ }^{20}$ To a stirred mixture of ferrocenecarboxylic acid $(4.6 \mathrm{~g}, 20 \mathrm{mmol})$ in $\mathrm{CH}_{2} \mathrm{Cl}_{2}(50 \mathrm{~mL})$ containing DMF (5 drops), was added dropwise oxalyl chloride $(3.5 \mathrm{~mL}, 40$ mmol). After $2 \mathrm{~h}$ at room temperature, the solvent and excess of oxalyl chloride were removed under vacuum. The crude ferrocenoyl chloride was next dissolved in $\mathrm{CH}_{2} \mathrm{Cl}_{2}(65 \mathrm{~mL})$ before dropwise addition of the required amine $(60 \mathrm{mmol})$ at $0{ }^{\circ} \mathrm{C}$. After stirring for 3 h, $1 \mathrm{M}$ aqueous $\mathrm{HCl}(30 \mathrm{~mL})$ was added. Extraction with $\mathrm{Et}_{2} \mathrm{O}(20$ $\mathrm{mL})$ and AcOEt $(2 \times 20 \mathrm{~mL})$, washing with brine $(20 \mathrm{~mL})$, drying over $\mathrm{MgSO}_{4}$, removal of the solvents and purification by chromatography on silica gel (the eluent is given in the product description) led to the expected compound (see Supporting Information for experimental data on the compound $\mathbf{1}$ ).

2-Iodo- $N, N$-diisopropylferrocenecarboxamide $(5$, racemic mixture). $\mathrm{To} \mathrm{Et}_{2} \mathrm{O}(15 \mathrm{~mL})$ containing TMEDA $(1.6 \mathrm{~g}, 2.1 \mathrm{~mL}, 13 \mathrm{mmol})$ was added dropwise at $-80{ }^{\circ} \mathrm{C}$, under stirring, BuLi ( 1.6 $\mathrm{M}$ in hexanes, $13 \mathrm{mmol}$ ). After $15 \mathrm{~min}$ at this temperature, a solution of $\mathrm{N}, \mathrm{N}$ diisopropylferrocenecarboxamide (1, $3.6 \mathrm{~g}, 11.5 \mathrm{mmol})$ in $\mathrm{Et}_{2} \mathrm{O}(20$ $\mathrm{mL}$ ) was added, and the mixture was stirred for $1 \mathrm{~h}$ before addition of a solution of $\mathrm{I}_{2}(5.8 \mathrm{~g}, 23 \mathrm{mmol})$ in $\mathrm{Et}_{2} \mathrm{O}(15 \mathrm{~mL})$ and THF $(8 \mathrm{~mL})$. After $30 \mathrm{~min}$ stirring, the cooling bath was removed and the mixture was allowed to reach room temperature. Addition of an aqueous saturated solution of $\mathrm{Na}_{2} \mathrm{~S}_{2} \mathrm{O}_{3}(75 \mathrm{~mL})$, extraction with $\mathrm{Et}_{2} \mathrm{O}(3 \times 20$ $\mathrm{mL}$ ), drying over $\mathrm{MgSO}_{4}$, removal of the solvents and purification by chromatography on silica gel (eluent: heptane-AcOEt 95:5; $R_{\mathrm{f}}=0.65$ ) gave 5 in $88 \%$ yield as an orange powder: $\mathrm{mp} 138{ }^{\circ} \mathrm{C}$; IR (ATR): 686 , $811,1002,1024,1036,1315,1368,1455,1620,2970,3094 \mathrm{~cm}^{-1} ;{ }^{1} \mathrm{H}$ NMR (300 MHz, $\left.\mathrm{CDCl}_{3}, 291 \mathrm{~K}\right) \delta 0.99\left(\right.$ br s, $\left.3 \mathrm{H}, \mathrm{CH}_{3}\right), 1.11$ (br s, $3 \mathrm{H}, \mathrm{CH}_{3}$ ), 1.51 (br s, $6 \mathrm{H}, 2 \mathrm{CH}_{3}$ ), 3.41 (br s, $1 \mathrm{H}, \mathrm{CHMe}$ ), 3.62 (br s, 1H, CHMe2), 4.17 (s, 1H, Cp-H), 4.28 (s, 1H, Cp-H), 4.34 (s, 5H, Cp$\mathrm{H}), 4.42(\mathrm{~s}, 1 \mathrm{H}, \mathrm{Cp}-\mathrm{H}) ;{ }^{1} \mathrm{H} \mathrm{NMR}\left(500 \mathrm{MHz}, \mathrm{CDCl}_{3}, 298 \mathrm{~K}\right) \delta 0.94(\mathrm{~d}$, $\left.3 \mathrm{H}, J=6.7 \mathrm{~Hz}, \mathrm{CH}_{3}\right), 1.05\left(\mathrm{~d}, 3 \mathrm{H}, J=6.8 \mathrm{~Hz}, \mathrm{CH}_{3}\right), 1.47(\mathrm{t}, 6 \mathrm{H}, J=$ $\left.6.2 \mathrm{~Hz}, \mathrm{CH}_{3}\right), 3.36\left(\mathrm{t}, 1 \mathrm{H}, J=7.1 \mathrm{~Hz}, \mathrm{C} H \mathrm{Me}_{2}\right), 3.57(\mathrm{t}, 1 \mathrm{H}, J=7.1$ $\mathrm{Hz}, \mathrm{CHMe}_{2}$ ), 4.13 (t, $\left.1 \mathrm{H}, J=2.4 \mathrm{~Hz}, \mathrm{H} 4\right), 4.24$ (dd, $1 \mathrm{H}, J=2.6$ and $1.3 \mathrm{~Hz}, \mathrm{H} 5), 4.30$ (s, 5H, Cp-H), 4.38 (dd, $1 \mathrm{H}, J=2.4$ and $1.3 \mathrm{~Hz}$, $\mathrm{H} 3$ ); ${ }^{1} \mathrm{H}$ NMR $\left(500 \mathrm{MHz},\left(\mathrm{CD}_{3}\right)_{2} \mathrm{SO}, 298 \mathrm{~K}\right) \delta 0.95$ (br s, $\left.3 \mathrm{H}, \mathrm{CH}_{3}\right)$, 1.04 (br s, $3 \mathrm{H}, \mathrm{CH}_{3}$ ), 1.41 (br s, $6 \mathrm{H}, 2 \mathrm{CH}_{3}$ ), 3.44 (br s, $1 \mathrm{H}, \mathrm{CHMe}$ ), 3.50 (br s, $\left.1 \mathrm{H}, \mathrm{C} H \mathrm{Me}_{2}\right), 4.27$ (t, $\left.1 \mathrm{H}, J=2.4 \mathrm{~Hz}\right), 4.28(\mathrm{~s}, 5 \mathrm{H}, \mathrm{Cp}-H)$, $4.41(\mathrm{dd}, 1 \mathrm{H}, J=2.5$ and $1.3 \mathrm{~Hz}), 4.50(\mathrm{dd}, 1 \mathrm{H}, J=2.4$ and $1.3 \mathrm{~Hz})$; ${ }^{1} \mathrm{H}$ NMR $\left(500 \mathrm{MHz},\left(\mathrm{CD}_{3}\right)_{2} \mathrm{SO}, 383 \mathrm{~K}\right) \delta 1.21(\mathrm{~d}, 6 \mathrm{H}, J=6.7 \mathrm{~Hz}$, $\left.\mathrm{CH}_{3}\right), 1.26\left(\mathrm{~d}, 6 \mathrm{H}, J=6.5 \mathrm{~Hz}, \mathrm{CH}_{3}\right), 3.56$ (sept, $2 \mathrm{H}, J=6.7 \mathrm{~Hz}$, $2 \mathrm{C} H \mathrm{Me}_{2}$ ), 4.27 (t, $\left.1 \mathrm{H}, J=2.5 \mathrm{~Hz}\right), 4.29$ (s, $\left.5 \mathrm{H}, \mathrm{Cp}\right), 4.38$ (br s, $1 \mathrm{H}$, $\mathrm{Cp}-\mathrm{H}), 4.48$ (br s, $1 \mathrm{H}, \mathrm{Cp}-\mathrm{H}) ;{ }^{13} \mathrm{C}$ NMR $\left(75 \mathrm{MHz}, \mathrm{CDCl}_{3}, 291 \mathrm{~K}\right) \delta$ $21.0\left(4 \mathrm{CH}_{3}\right), 40.6(\mathrm{C}-\mathrm{I}), 46.0\left(\mathrm{CHMe}_{2}\right), 50.9\left(\mathrm{CHMe}_{2}\right), 66.9(\mathrm{CH})$, $67.7(\mathrm{CH}), 72.9(5 \mathrm{CH}, \mathrm{Cp}), 73.7(\mathrm{CH}), 92.8(\mathrm{C}-\mathrm{C}=\mathrm{O}), 166.4(\mathrm{C}=\mathrm{O})$; ${ }^{13} \mathrm{C}$ NMR $\left(126 \mathrm{MHz}, \mathrm{CDCl}_{3}, 298 \mathrm{~K}\right) \delta 20.7\left(\mathrm{CH}_{3}\right), 20.8\left(\mathrm{CH}_{3}\right), 21.0$ $\left(\mathrm{CH}_{3}\right), 21.0\left(\mathrm{CH}_{3}\right), 40.5(\mathrm{C}-\mathrm{I}), 45.9\left(\mathrm{CHMe}_{2}\right), 50.8\left(\mathrm{CHMe}_{2}\right), 66.8$ $(\mathrm{CH}, \mathrm{C} 5), 67.7(\mathrm{CH}, \mathrm{C} 4), 72.7(5 \mathrm{CH}, \mathrm{Cp}), 73.6(\mathrm{CH}, \mathrm{C} 3), 92.6(\mathrm{C}-$ $\mathrm{C}=\mathrm{O}), 166.3(\mathrm{C}=\mathrm{O})$. These data are similar to those reported previously. ${ }^{3 a}$ The obtained crystal structure was found to be similar to that described (CCDC 170421; NEMLAS). ${ }^{21}$

General procedure 3. To a stirred, cooled $\left(0{ }^{\circ} \mathrm{C}\right)$ solution of $\mathrm{H}-$ TMP $(0.85 \mathrm{~mL}, 5.0 \mathrm{mmol})$ in THF $(4 \mathrm{~mL})$ were successively added $\operatorname{BuLi}(\sim 1.6 \mathrm{M}$ in hexanes, $4.5 \mathrm{mmol})$ and, $5 \mathrm{~min}$ later, $\mathrm{ZnCl}_{2} \cdot \mathrm{TMEDA}^{42}(0.38 \mathrm{~g}, 1.5 \mathrm{mmol})$. The mixture was stirred for 10 min at $0{ }^{\circ} \mathrm{C}$ before introduction of the required ferrocene $(3.0 \mathrm{mmol})$ at $0-10{ }^{\circ} \mathrm{C}$. After $2 \mathrm{~h}$ at room temperature, a solution of $\mathrm{I}_{2}(0.75 \mathrm{~g}, 3.0$ $\mathrm{mmol})$ in THF (4 mL) was added. The mixture was stirred overnight before addition of an aqueous saturated solution of $\mathrm{Na}_{2} \mathrm{~S}_{2} \mathrm{O}_{3}(10 \mathrm{~mL})$ and extraction with AcOEt $(3 \times 20 \mathrm{~mL})$. The combined organic layers were dried over $\mathrm{MgSO}_{4}$, and concentrated under reduced pressure. The crude product was purified by chromatography over silica gel (the eluent is given in the product description; see Supporting Information for experimental data on the compound 6 ).

2-Iodo- $N, N$-dimethylferrocenecarboxamide $(7$, racemic mixture). The general procedure 3 using $N, N$-dimethylferrocenecarboxamide $(\mathbf{3}, 0.77 \mathrm{~g})$ gave 7 (eluent: heptane-AcOEt 70:30; $\mathrm{R}_{\mathrm{f}}=$ 0.28 ) in $78 \%$ yield as an orange powder: $m p 58{ }^{\circ} \mathrm{C}$; IR (ATR): 689 , 816, 872, 961, 999, 1008, 1106, 1117, 1224, 1262, 1360, 1379, 1418, 1453, 1496, 1631, $2926 \mathrm{~cm}^{-1}$; ${ }^{1} \mathrm{H}$ NMR (500 MHz, $\left.\mathrm{CDCl}_{3}, 298 \mathrm{~K}\right) \delta$ 2.71 (br s, $3 \mathrm{H}, \mathrm{CH}_{3}$ ), 2.92 (br s, $3 \mathrm{H}, \mathrm{CH}_{3}$ ), 4.13 (t, $1 \mathrm{H}, J=2.5 \mathrm{~Hz}, \mathrm{Cp}-$ 
H), $4.21(\mathrm{~s}, 5 \mathrm{H}, \mathrm{Cp}), 4.26(\mathrm{dd}, 1 \mathrm{H}, J=2.6$ and $1.3 \mathrm{~Hz}, \mathrm{Cp}-\mathrm{H}), 4.37$ (dd, $1 \mathrm{H}, J=2.4$ and $1.3 \mathrm{~Hz}, \mathrm{Cp}-\mathrm{H}) ;{ }^{13} \mathrm{C}$ NMR $\left(126 \mathrm{MHz}, \mathrm{CDCl}_{3}, 298\right.$ K) $\delta 35.3\left(\mathrm{CH}_{3}\right), 38.8\left(\mathrm{CH}_{3}\right), 40.3(\mathrm{C}-\mathrm{I}), 68.3(\mathrm{CH}), 68.4(\mathrm{CH}), 72.7$ $(5 \mathrm{CH}, \mathrm{Cp}), 74.4(\mathrm{CH}), 87.7(\mathrm{C}-\mathrm{C}=\mathrm{O}), 167.8(\mathrm{C}=\mathrm{O})$. Anal. Calcd for $\mathrm{C}_{13} \mathrm{H}_{14} \mathrm{FeINO}$ : C, 40.77; H, 3.68; N, 3.66. Found: C, 40.84; H, 3.71; N, 3.69. Crystal data for 7. $\mathrm{C}_{13} \mathrm{H}_{14} \mathrm{FeINO}, M=383.00, T=150(2) \mathrm{K}$, orthorhombic, $P 2{ }_{1} 2_{1} 2_{1}, a=7.3581(8), b=9.0317(11), c=19.773(3)$ $\AA, V=1314.0(3) \AA^{3}, Z=4, d=1.936 \mathrm{~g} \mathrm{~cm}^{-3}, \mu=3.480 \mathrm{~mm}^{-1}$. A final refinement on $F^{2}$ with 2939 unique intensities and 157 parameters converged at $\omega R\left(F^{2}\right)=0.0398(R(F)=0.0162)$ for 2914 observed reflections with $I>2 \sigma(I)$. CCDC 1565040 .

1-Iodo-2-(4-morpholinocarbonyl)ferrocene $(8$, racemic mixture). The general procedure 3 using (4-morpholinocarbonyl)ferrocene $(4,0.90 \mathrm{~g})$ gave 8 (eluent: heptane-AcOEt 80:20; $\mathrm{R}_{\mathrm{f}}=0.18$ ) in $84 \%$ yield as a yellowish powder: $\mathrm{mp} 135-136{ }^{\circ} \mathrm{C}$; IR (ATR): 687 , 810, 866, 959, 1001, 1021, 1062, 1111, 1186, 1250, 1273, 1404, 1437, 1466, 2363, 2856, 2971, $3081 \mathrm{~cm}^{-1}$; ${ }^{1} \mathrm{H}$ NMR $(300 \mathrm{MHz}$, $\mathrm{CDCl}_{3}, 291 \mathrm{~K}$ ) $\delta 3.45$ (br s, $3 \mathrm{H}, \mathrm{CH}_{2}$ ), 3.66 (br s, $5 \mathrm{H}, \mathrm{CH}_{2}$ ), 4.25 (br s, $1 \mathrm{H}, \mathrm{Cp}-\mathrm{H}), 4.34$ (s, 5H, Cp), 4.36 (br s, $1 \mathrm{H}, \mathrm{Cp}-\mathrm{H}$ ), 4.49 (br s, $1 \mathrm{H}$, $\mathrm{Cp}-\mathrm{H}) ;{ }^{13} \mathrm{C}$ NMR $\left(75 \mathrm{MHz}, \mathrm{CDCl}_{3}, 291 \mathrm{~K}\right) \delta 40.2(\mathrm{C}-\mathrm{I}), 43.1\left(2 \mathrm{CH}_{2}\right)$, $47.8\left(2 \mathrm{CH}_{2}\right), 67.0(\mathrm{CH}), 68.8(\mathrm{CH}), 73.1(5 \mathrm{CH}, \mathrm{Cp}), 74.8(\mathrm{CH}), 87.6$ $(C-\mathrm{C}=\mathrm{O}), 167.1(\mathrm{C}=\mathrm{O})$. Anal. Calcd for $\mathrm{C}_{15} \mathrm{H}_{16}$ FeINO: $\mathrm{C}, 42.39 ; \mathrm{H}$, 3.79; N, 3.30. Found: $\mathrm{C}, 42.45 ; \mathrm{H}, 3.86$; N, 3.33. Crystal data for 8 . $\mathrm{C}_{15} \mathrm{H}_{16} \mathrm{FeINO}_{2}, M=425.04, T=150(2) \mathrm{K}$, monoclinic, $P 2_{1} / c, a=$ 10.3514(15), $b=7.2576(10), c=20.081(3) \AA, \beta=101.480(4)^{\circ}, V=$ $1478.5(3) \AA^{3}, Z=4, d=1.910 \mathrm{~g} \mathrm{~cm}^{-3}, \mu=3.108 \mathrm{~mm}^{-1}$. A final refinement on $F^{2}$ with 3368 unique intensities and 148 parameters converged at $\omega R\left(F^{2}\right)=0.0859(R(F)=0.0351)$ for 3211 observed reflections with $I>2 \sigma(I)$. CCDC 1565041 .

General procedure 4. To a stirred, cooled $\left(0{ }^{\circ} \mathrm{C}\right)$ solution of $\mathrm{H}-$ TMP $(0.19 \mathrm{~mL}, 1.1 \mathrm{mmol})$ in THF $(2 \mathrm{~mL})$ was added BuLi $(\sim 1.6 \mathrm{M}$ in hexane, $1.1 \mathrm{mmol})$. The mixture was stirred for $5 \mathrm{~min}$ at $0{ }^{\circ} \mathrm{C}$ before introduction of the required iodoferrocene $(1.0 \mathrm{mmol})$ at $-50^{\circ} \mathrm{C}$. After $14 \mathrm{~h}$ at $-50{ }^{\circ} \mathrm{C}, \mathrm{MeOH}(2.0 \mathrm{~mL})$ and aqueous $1 \mathrm{M} \mathrm{HCl}(10 \mathrm{~mL})$ were successively added. Extraction with AcOEt $(3 \times 15 \mathrm{~mL})$, drying over $\mathrm{MgSO}_{4}$, concentration under reduced pressure, and purification by azeotropic reflux chromatography ${ }^{43}$ over silica gel (eluent: cyclohexane-AcOiPr 78:22) led to the expected product.

3-Iodo- $N, N$-diisopropylferrocenecarboxamide $(9$, racemic mixture). The general procedure 4 using 2-iodo- $N, N$ diisopropylferrocenecarboxamide $(5,0.44 \mathrm{~g})$ gave $9\left(\mathrm{R}_{\mathrm{f}}=0.32\right)$ in $36 \%$ yield (53\% yield on a $4.0 \mathrm{mmol} \mathrm{scale}$ ) as an orange powder: $\mathrm{mp}$ $112{ }^{\circ} \mathrm{C}$; IR (ATR): 763, 803, 825, 1007, 1033, 1324, 1368, 1457, $1602,2959,3005 \mathrm{~cm}^{-1} ;{ }^{1} \mathrm{H}$ NMR $\left(300 \mathrm{MHz}, \mathrm{CDCl}_{3}, 291 \mathrm{~K}\right) \delta 1.25-$ 1.40 (br s, $12 \mathrm{H}, 4 \mathrm{CH}_{3}$ ), 3.44 (br s, $1 \mathrm{H}, \mathrm{CHMe}$ ), 4.25 (s, $5 \mathrm{H}, \mathrm{Cp}$ ), 4.40 (br s, $1 \mathrm{H}, \mathrm{CHMe}$ ), 4.50 (dd, $1 \mathrm{H}, J=2.5$ and $1.2 \mathrm{~Hz}, \mathrm{Cp}-\mathrm{H}$ ), 4.57 (dd, $1 \mathrm{H}, J=2.5$ and $1.4 \mathrm{~Hz}, \mathrm{Cp}-\mathrm{H}), 4.73(\mathrm{t}, 1 \mathrm{H}, J=1.3 \mathrm{~Hz}, \mathrm{Cp}-\mathrm{H}) ;{ }^{1} \mathrm{H}$ NMR $\left(500 \mathrm{MHz}, \mathrm{CDCl}_{3}, 298 \mathrm{~K}\right.$ ) $\delta 1.20\left(\right.$ br s, $\left.6 \mathrm{H}, 2 \mathrm{CH}_{3}\right), 1.45$ (br s, $6 \mathrm{H}, 2 \mathrm{CH}_{3}$ ), 3.42 (br s, $1 \mathrm{H}, \mathrm{CHMe}$ ), 4.30 (s, 5H, Cp), 4.45 (br s, $1 \mathrm{H}$, $\left.\mathrm{C} H \mathrm{Me}_{2}\right), 4.51(\mathrm{~s}, 1 \mathrm{H}, \mathrm{H} 4), 4.58(\mathrm{~s}, 1 \mathrm{H}, \mathrm{H} 5), 4.73(\mathrm{~s}, 1 \mathrm{H}, \mathrm{H} 2) ;{ }^{13} \mathrm{C}$ NMR $\left(75 \mathrm{MHz}, \mathrm{CDCl}_{3}, 291 \mathrm{~K}\right) \delta 21.2\left(4 \mathrm{CH}_{3}\right), 39.6(\mathrm{C}-\mathrm{I}), 46.6$ $\left(\mathrm{CHMe}_{2}\right), 49.5\left(\mathrm{CHMe}_{2}\right), 71.1(\mathrm{CH}), 73.0(5 \mathrm{CH}, \mathrm{Cp}), 75.2(\mathrm{CH}), 75.6$ (CH), $82.9(C-\mathrm{C}=\mathrm{O}), 167.8(\mathrm{C}=\mathrm{O}) ;{ }^{13} \mathrm{C}$ NMR $\left(126 \mathrm{MHz}, \mathrm{CDCl}_{3}, 298\right.$ K) $\delta 21.2\left(4 \mathrm{CH}_{3}\right), 39.6(\mathrm{C}-\mathrm{I}), 46.5\left(\mathrm{CHMe}_{2}\right), 49.9\left(\mathrm{CHMe}_{2}\right), 71.1$ (CH, C5), $73.0(5 \mathrm{CH}, \mathrm{Cp}), 75.2(\mathrm{CH}, \mathrm{C} 4), 75.6(\mathrm{CH}, \mathrm{C} 2), 82.8(C-$ $\mathrm{C}=\mathrm{O}), 167.8(\mathrm{C}=\mathrm{O})$. Anal. Calcd for $\mathrm{C}_{17} \mathrm{H}_{22} \mathrm{FeINO}$ : C, 46.50; H, 5.05; N, 3.19. Found: C, 46.61; H, 5.10; N, 3.29. Crystal data for 9. $\mathrm{C}_{17} \mathrm{H}_{22} \mathrm{FeINO}, M=439.10, T=293(2) \mathrm{K}$, monoclinic, $P 2{ }_{1} / n, a=$ 7.5144(6), $b=10.3128(8), c=22.4379(17) \AA, \beta=91.475(3)^{\circ}, V=$ 1738.2(2) $\AA^{3}, Z=4, d=1.678 \mathrm{~g} \mathrm{~cm}^{-3}, \mu=2.642 \mathrm{~mm}^{-1}$. A final refinement on $F^{2}$ with 3955 unique intensities and 194 parameters converged at $\omega R\left(F^{2}\right)=0.3102(R(F)=0.1108)$ for 3229 observed reflections with $I>2 \sigma(I)$. CCDC 1565042.

$\mathrm{N}, \mathrm{N}$-Diethyl-3-iodoferrocenecarboxamide $(10$, racemic mixture). The general procedure 4 using 2-iodo- $N, N$ diethylferrocenecarboxamide $(\mathbf{6}, 0.41 \mathrm{~g}, 1.0 \mathrm{mmol})$ gave $\mathbf{1 0}\left(\mathrm{R}_{\mathrm{f}}=\right.$ 0.10 ) in $32 \%$ yield as an orange powder: $\mathrm{mp} 86-87{ }^{\circ} \mathrm{C}$; IR (ATR):
$668,823,1001,1209,1449,1474,1604,2967 \mathrm{~cm}^{-1} ;{ }^{1} \mathrm{H}$ NMR $(500$ $\left.\mathrm{MHz}_{2} \mathrm{CDCl}_{3}, 298 \mathrm{~K}\right) \delta 1.16\left(\mathrm{t}, 6 \mathrm{H}, J=6.9 \mathrm{~Hz}, 2 \mathrm{CH}_{3}\right), 3.42($ br s, $4 \mathrm{H}$, $\left.2 \mathrm{CH}_{2}\right), 4.21(\mathrm{~s}, 5 \mathrm{H}, \mathrm{Cp}), 4.51(\mathrm{dd}, 1 \mathrm{H}, J=2.5$ and $1.3 \mathrm{~Hz}, \mathrm{H} 4), 4.60$ $(\mathrm{dd}, 1 \mathrm{H}, J=2.6$ and $1.4 \mathrm{~Hz}, \mathrm{H} 5), 4.77(\mathrm{t}, 1 \mathrm{H}, J=1.4 \mathrm{~Hz}, \mathrm{H} 2) ;{ }^{13} \mathrm{C}$ NMR $\left(126 \mathrm{MHz}, \mathrm{CDCl}_{3}, 298 \mathrm{~K}\right) \delta 12.9\left(\mathrm{CH}_{3}\right), 14.8\left(\mathrm{CH}_{3}\right), 39.6(\mathrm{C}-\mathrm{I})$, $40.9\left(\mathrm{CH}_{2}\right), 42.7\left(\mathrm{CH}_{2}\right), 71.2(\mathrm{CH}, \mathrm{C} 5), 72.9(5 \mathrm{CH}, \mathrm{Cp}), 75.5(\mathrm{CH}$, C4), 75.9 (CH, C2), $80.3(C-\mathrm{C}=\mathrm{O}), 168.1(\mathrm{C}=\mathrm{O})$.

General procedure 5 (Suzuki coupling). The protocol was adapted from a previously reported procedure. ${ }^{36}$ A solution of $\mathrm{CsF}$ $(0.30 \mathrm{~g}, 2.0 \mathrm{mmol}), 3$-iodo- $N, N$-diisopropylferrocenecarboxamide (9, $0.44 \mathrm{~g}, 1.0 \mathrm{mmol})$ and boronic acid $(4.0 \mathrm{mmol})$ in toluene $(10 \mathrm{~mL})$ was degassed with Ar before addition of $\mathrm{Pd}(\mathrm{dba})_{2}(28 \mathrm{mg}, 50 \mu \mathrm{mol})$ and $\mathrm{PPh}_{3}(52 \mathrm{mg}, 0.20 \mathrm{mmol})$. The resulting mixture was heated for $14 \mathrm{~h}$ under reflux before cooling and dilution with $\mathrm{Et}_{2} \mathrm{O}(60 \mathrm{~mL})$, washing with $\mathrm{H}_{2} \mathrm{O}$, and extraction with $\mathrm{CH}_{2} \mathrm{Cl}_{2}(3 \times 20 \mathrm{~mL})$. After drying over anhydrous $\mathrm{Na}_{2} \mathrm{SO}_{4}$, the solvent was evaporated under reduced pressure, and the coupled product was isolated by purification by flash chromatography on silica gel.

\section{$\mathrm{N}, \mathrm{N}$-Diisopropyl-3-(4-methoxyphenyl)ferrocenecarboxamide} (13, racemic mixture). The general procedure 5 using 4methoxyphenylboronic acid $(0.61 \mathrm{~g})$ gave 13 (eluent: heptane-AcOEt $80: 20 ; R_{\mathrm{f}}=0.43$ ) in $46 \%$ yield as an orange powder (slow cristallization): $\mathrm{mp} 134-136{ }^{\circ} \mathrm{C}$; IR (ATR): 791, 807, 831, 1024, 1036, 1158, 1178, 1246, 1272, 1321, 1342, 1372, 1437, 1452, 1467, 1525, 1609, 2929, 2965, $3001 \mathrm{~cm}^{-1} ;{ }^{1} \mathrm{H}$ NMR (500 MHz, CDCl $\left.32,298 \mathrm{~K}\right) \delta 1.15-$ 1.36 (br s, $\left.6 \mathrm{H}, 2 \mathrm{CH}_{3}\right), 1.40-1.58\left(\right.$ br s, $\left.6 \mathrm{H}, 2 \mathrm{CH}_{3}\right), 3.45$ (br s, $1 \mathrm{H}$, $\left.\mathrm{C} H \mathrm{Me}_{2}\right), 3.82\left(\mathrm{~s}, 3 \mathrm{H}, \mathrm{OCH}_{3}\right), 4.10(\mathrm{~s}, 5 \mathrm{H}, \mathrm{Cp}), 4.56(\mathrm{br} \mathrm{s}, 1 \mathrm{H}$, $\mathrm{CHMe}_{2}$ ), 4.64 (dd, $1 \mathrm{H}, J=2.5$ and $\left.1.4 \mathrm{~Hz}, \mathrm{Cp}-\mathrm{H}, \mathrm{H} 5\right), 4.67(\mathrm{dd}, 1 \mathrm{H}, J$ $=2.4$ and $1.5 \mathrm{~Hz}, \mathrm{Cp}-\mathrm{H}, \mathrm{H} 4), 5.01(\mathrm{t}, 1 \mathrm{H}, J=1.4 \mathrm{~Hz}, \mathrm{Cp}-\mathrm{H}, \mathrm{H} 2)$, 6.85-6.89 (m, 2H, H3'), 7.41-7.43 (m, 2H, H2'); ${ }^{13} \mathrm{C}$ NMR (126 MHz, $\left.\mathrm{CDCl}_{3}, 298 \mathrm{~K}\right) \delta 21.3\left(4 \mathrm{CH}_{3}\right), 46.5\left(\mathrm{CHMe}_{2}\right), 49.6\left(\mathrm{CHMe}_{2}\right), 55.4$ $\left(\mathrm{OCH}_{3}\right), 66.9(\mathrm{CH}, \mathrm{C} 4), 68.3(\mathrm{CH}, \mathrm{C} 2), 70.1(\mathrm{CH}, \mathrm{C} 5), 71.4(5 \mathrm{CH}$, Cp), $81.7(C-\mathrm{C}=\mathrm{O}), 86.8(\mathrm{C}, \mathrm{C} 3), 114.1\left(2 \mathrm{CH}, \mathrm{C} 3{ }^{\prime}\right), 127.3(2 \mathrm{CH}$, C2'), 130.3 (C, C1'), 158.5 (C, C4'), $169.5(\mathrm{C}=\mathrm{O})$. Anal. Calcd for $\mathrm{C}_{24} \mathrm{H}_{29} \mathrm{FeNO}_{2}$ : C, 68.74; H, 6.97; N, 3.34. Found: C, 68.70; H, 6.88; N, 3.31. Crystal data for 13. $\mathrm{C}_{24} \mathrm{H}_{29} \mathrm{FeNO}_{2}, M=419.33, T=150(2)$ $\mathrm{K}$, orthorhombic, $P 2_{1} c n, a=6.0222(2), b=13.0671(5), c=$ 26.0685(8) $\AA, V=2051.40(12) \AA^{3}, Z=4, d=1.358 \mathrm{~g} \mathrm{~cm}^{-3}, \mu=0.754$ $\mathrm{mm}^{-1}$. A final refinement on $F^{2}$ with 4632 unique intensities and 225 parameters converged at $\omega R\left(F^{2}\right)=0.0998(R(F)=0.0440)$ for 4212 observed reflections with $I>2 \sigma(I)$. CCDC 1565043 .

\section{$N, N$-Diisopropyl-3-(4-(trifluoromethylphenyl))ferrocene-}

carboxamide (14, racemic mixture). The general procedure 5 using 4-(trifluoromethyl)phenylboronic acid (0.76 g) gave 14 (eluent: heptane-AcOEt $85: 15 ; \mathrm{R}_{\mathrm{f}}=0.23$ ) in $26 \%$ yield as an orange oil: IR (ATR): 690, 729, 807, 822, 842, 908, 1040, 1068, 1106, 1121, 1162, 1285, 1321, 1371, 1446, 1468, 1615, 2241, 2933, $2969 \mathrm{~cm}^{-1} ;{ }^{1} \mathrm{H}$ NMR $\left(500 \mathrm{MHz}, \mathrm{CDCl}_{3}, 298 \mathrm{~K}\right) \delta 1.15-1.35$ (br s, $\left.6 \mathrm{H}, 2 \mathrm{CH}_{3}\right), 1.40-1.60(\mathrm{br}$ s, 6H, 2- $\mathrm{CH}_{3}$ ), 3.47 (br s, $1 \mathrm{H}, \mathrm{CHMe}$ ), 4.12 (s, 5H, Cp), 4.62 (br s, $1 \mathrm{H}, \mathrm{CHMe}$ ), 4.72 (dd, $1 \mathrm{H}, J=2.6$ and $1.4 \mathrm{~Hz}, \mathrm{Cp}-\mathrm{H}, \mathrm{H} 5), 4.77$ (dd, $1 \mathrm{H}, J=2.6$ and $1.5 \mathrm{~Hz}, \mathrm{Cp}-\mathrm{H}, \mathrm{H} 4), 5.12(\mathrm{t}, 1 \mathrm{H}, J=1.8 \mathrm{~Hz}, \mathrm{Cp}-\mathrm{H}$, $\mathrm{H} 2), 7.54\left(\mathrm{~d}, 2 \mathrm{H}, J=8.6 \mathrm{~Hz}, \mathrm{H} 2\right.$ '), $7.57\left(\mathrm{~d}, 2 \mathrm{H}, J=8.5 \mathrm{~Hz}, \mathrm{H} 3{ }^{\prime}\right) ;{ }^{13} \mathrm{C}$ NMR $\left(126 \mathrm{MHz}, \mathrm{CDCl}_{3}, 298 \mathrm{~K}\right) \delta 21.3\left(4 \mathrm{CH}_{3}\right), 46.5\left(\mathrm{CHMe}_{2}\right), 49.9$ $\left(\mathrm{CHMe}_{2}\right), 67.3(\mathrm{CH}, \mathrm{C} 4), 69.1(\mathrm{CH}, \mathrm{C} 2), 70.9(\mathrm{CH}, \mathrm{C} 5), 71.7(5 \mathrm{CH}$, Cp), $83.4(C-\mathrm{C}=\mathrm{O}), 84.0(\mathrm{C}, \mathrm{C} 3), 125.6\left(\mathrm{q}, 2 \mathrm{CH}, J=3.8 \mathrm{~Hz}, \mathrm{C}^{\prime}\right)$, 126.2 (2CH, C2'), 128.3 (C, $J=32.5 \mathrm{~Hz}, \mathrm{C}^{\prime}$ '), 124.5 (q, C, $J=272$ $\left.\mathrm{Hz}, \mathrm{CF}_{3}\right), 142.8\left(\mathrm{C} 1\right.$ ') $168.7(\mathrm{C}=\mathrm{O}) ;{ }^{19} \mathrm{~F}$ NMR (126 MHz, $\mathrm{CDCl}_{3}, 291$ K) $\delta$-62.5. Anal. Calcd for $\mathrm{C}_{24} \mathrm{H}_{26} \mathrm{~F}_{3} \mathrm{FeNO}: \mathrm{C}, 63.03 ; \mathrm{H}, 5.73 ; \mathrm{N}$, 3.06. Found: C, 63.12; H, 5.75; N, 2.98 .

1-( $N, N$-Diisopropylaminomethyl)-3-iodoferrocene $(15$, racemic mixture). The protocol was adapted from a previously reported procedure. ${ }^{3 a}$ To a stirred solution of 3-iodo- $N, N$-diisopropylferrocenecarboxamide $(9,1.0 \mathrm{mmol}, 0.44 \mathrm{~g})$ in THF $(10 \mathrm{~mL})$ under argon was added $\mathrm{BH}_{3}$. THF $(5.0 \mathrm{mmol}, 5.0 \mathrm{~mL}$ of a $1.0 \mathrm{M}$ solution). The mixture was refluxed for $16 \mathrm{~h}$, cooled to room temperature, quenched by $10 \%$ aqueous $\mathrm{KOH}(35 \mathrm{~mL})$ and refluxed for $10 \mathrm{~h}$. The resulting solution was cooled to room temperature. Brine $(50 \mathrm{~mL})$ was added before 
extraction with $\mathrm{Et}_{2} \mathrm{O}(3 \times 20 \mathrm{~mL})$, drying over $\mathrm{MgSO}_{4}$, concentration under reduced pressure, and purification by chromatography over silica gel (eluent: heptane-AcOEt 60:40 to 0:100). The compound 15 was isolated in $68 \%$ yield: yellow oil; IR (ATR): 748, 818, 871, 933, 1001, 1031, 1106, 1137, 1160, 1202, 1362, 1463, 1673, 2926, 2961, $3096 \mathrm{~cm}^{-1} ;{ }^{1} \mathrm{H}$ NMR $\left(500 \mathrm{MHz}, \mathrm{CDCl}_{3}, 298 \mathrm{~K}\right) \delta 0.98-1.01(\mathrm{~m}, 12 \mathrm{H}$, $4 \mathrm{CH}_{3}$ ), 3.03 (sept, $2 \mathrm{H}, J=6.6 \mathrm{~Hz}, 2 \mathrm{CHMe}_{2}$ ), 3.34 (d, $1 \mathrm{H}, J=14.4$ $\mathrm{Hz}, \mathrm{CH}_{2} \mathrm{~N}$ ), $3.40\left(\mathrm{~d}, 1 \mathrm{H}, J=14.5 \mathrm{~Hz}, \mathrm{CH}_{2} \mathrm{~N}\right), 4.13$ (s, $\left.5 \mathrm{H}, \mathrm{Cp}\right), 4.20$ (s, 1H, H5), 4.31 (s, 1H, H4), $4.46(\mathrm{~s}, 1 \mathrm{H}, \mathrm{H} 2) ;{ }^{13} \mathrm{C}$ NMR $(126 \mathrm{MHz}$, $\left.\mathrm{CDCl}_{3}, 298 \mathrm{~K}\right) \delta 20.9\left(4 \mathrm{CH}_{3}\right), 39.8(\mathrm{C}-\mathrm{I}), 43.8\left(\mathrm{CH}_{2} \mathrm{~N}\right), 47.6$ $\left(2 \mathrm{CHMe}_{2}\right), 70.1(\mathrm{CH}, \mathrm{C} 5), 71.7(5 \mathrm{CH}, \mathrm{Cp}), 73.7(\mathrm{CH}, \mathrm{C} 4), 75.9(\mathrm{CH}$, C2), $89.9\left(C-\mathrm{CH}_{2}\right)$. Anal. Calcd for $\mathrm{C}_{17} \mathrm{H}_{24} \mathrm{FeIN}$ : C, 48.03; H, 5.69; N, 3.29. Found: C, 48.11; H, 5.73; N, 3.12.

Density Functional Theory (DFT) Calculation Details. All the DFT calculations were performed by using the Gaussian 09 software package. ${ }^{44}$ The structures from the X-ray diffraction analysis were used as starting guess. All the molecular geometries were completely optimized with no constraints. We used the B3LYP hybrid functional ${ }^{45}$ together with the LANL2DZ basis set for both Fe and I, and the $6-31 \mathrm{G}(\mathrm{d})$ basis set for the other atoms to calculate the optimized geometries and vibrational frequencies. Relaxed PES scans for $\mathbf{1}$ and $\mathbf{5}$ were obtained at the same level of theory. The solvent influence was treated by using the polarized continuum model (IEF $\mathrm{PCM})^{46}$ with the default parameters for THF. The $\mathrm{p} K_{\mathrm{a}}$ values were calculated from the Gibbs energy of the homodesmic reaction between the studied and probe aromatic substrates. ${ }^{47}$ The single point energies were obtained at the CAM-B3LYP/LANL2DZ + 6$31+G(d, p)$ level of theory. ${ }^{48}$

\section{ASSOCIATED CONTENT}

\section{Supporting Information}

The Supporting Information is available free of charge on the ACS Publications website. NMR spectra (PDF) Crystallographic data (CIF) DFT structural data

\section{AUTHOR INFORMATION}

\section{Corresponding Author}

*E-mail: william.erb@univ-rennes1.fr; ORCID: 0000-0002-2906-2091

*E-mail: hys@tut.by

\section{Notes}

The authors declare no competing financial interest.

\section{ACKNOWLEDGMENT}

This work was supported by the Ministère de l'Enseignement supérieur, de la Recherche et de l'Innovation (grant to M. T.) and the Université de Rennes 1. We also thank the Centre National de la Recherche Scientifique, the Institut Universitaire de France and Rennes Métropole. We acknowledge FEDER founds (D8 VENTURE Bruker AXS diffractometer) and Thermofisher (generous gift of H-TMP).

\section{REFERENCES}

(1) (a) Colacot, T. J. Chem. Rev. 2003, 103, 3101-3118. (b) Gómez-Arrayás, R.; Adrio, J.; Carretero, J. C. Angew. Chem. Int. Ed. 2006, 45, 7674-7715. (c) Ferrocenes: Compounds, Properties and Applications, Phillips, E. S., Ed.; Nova Science Publisher's: New York, 2011. (d) Butt, N. A.; Liu, D.; Zhang, W. Synlett 2014, 25, $615-$ 630. (e) Jaouen, G.; Vessières, A.; Top, S. Chem. Soc. Rev. 2015, 44, 8802-8817. (f) Scottwell, S. Ø.; Crowley, J. D. Chem. Commun. 2016, 52, 2451-2464. (g) Astruc, D. Eur. J. Inorg. Chem. 2017, 2017, 6-29.

(2) (a) Richards, C. J.; Locke, A. J. Tetrahedron: Asymmetry 1998, 9, 2377-2407. (b) Sutcliffe, O. B.; Bryce, M. R. Tetrahedron: Asymmetry 2003, 14, 2297-2325. (c) Atkinson, R. C. J.; Gibson, V. C.; Long, N. J. Chem. Soc. Rev. 2004, 33, 313-328. (d) Ferber, B.; Kagan, H. B. Adv. Synth. Catal. 2007, 349, 493-507. (e) Bonini, B. F.; Fochi, M.; Ricci, A. Synlett 2007, 360-373. (f) Butler, I. R. Eur. J. Inorg. Chem. 2012, 2012, 4387-4406. (g) Schaarschmidt, D.; Lang, H. Organometallics 2013, 32, 5668-5704. (h) Zhu, D.-Y.; Chen, P.; Xia, J.-B. ChemCatChem 2016, 8, 68-73. (i) Gao, D.-W.; Gu, Q.; Zheng, C.; You, S.-L. Acc. Chem. Res. 2017, 50, 351-365.

(3) (a) Tsukazaki, M.; Tinkl, M.; Roglans, A.; Chapell, B. J.; Taylor, N. J.; Snieckus, V. J. Am. Chem. Soc. 1996, 118, 685-686. (b) Miao, B.; Tinkl, M.; Snieckus, V. Tetrahedron Lett. 1999, 40, 24492452. (c) Metallinos, C.; Szillat, H.; Taylor, N. J.; Snieckus, V. Adv. Synth. Catal. 2003, 345, 370-382. (d) Stavrakov, G.; Philipova, I.; Ivanova, B.; Dimitrov, V. Tetrahedron: Asymmetry 2010, 21, 18451854. (e) Philipova, I.; Stavrakov, G.; Chimov, A.; Nikolova, R.; Shivachev, B.; Dimitrov, V. Tetrahedron: Asymmetry 2011, 22, 970979.

(4) (a) Herbert, S. A.; Castell, D. C.; Clayden, J.; Arnott, G. E. Org. Lett. 2013, 15, 3334-3337. (b) Arthurs, R. A.; Richards, C. J. Org. Lett. 2017, 19, 702-705.

(5) (a) Deschenaux, R.; Marendaz, J. L. J. Chem. Soc., Chem. Commun. 1991, 909-910. (b) Farrington, E. J.; Martinez Viviente, E.; Williams, B. S.; van Koten, G.; Brown, J. M. Chem. Commun. 2002, 308-309. (c) Westwood, J.; Coles, S. J.; Collinson, S. R.; Gasser, G.; Green, S. J.; Hursthouse, M. B.; Light, M. E.; Tucker, J. H. R. Organometallics 2004, 23, 946-951. (d) Koridze, A. A.; Kuklin, S. A.; Sheloumov, A. M.; Dolgushin, F. M.; Lagunova, V. Y.; Petukhova, I. I.; Ezernitskaya, M. G.; Peregudov, A. S.; Petrovskii, P. V.; Vorontsov, E. V.; Baya, M.; Poli, R. Organometallics 2004, 23, 4585-4593. (e) Kuklin, S. A.; Sheloumov, A. M.; Dolgushin, F. M.; Ezernitskaya, M. G.; Peregudov, A. S.; Petrovskii, P. V.; Koridze, A. A. Organometallics 2006, 25, 5466-5476. (f) Muraoka, T.; Kinbara, K.; Aida, T. Nature 2006, 440, 512-515. (g) Muraoka, T.; Kinbara, K.; Wakamiya, A.; Yamaguchi, S.; Aida, T. Chem. - Eur. J. 2007, 13, 1724-1730. (h) Kai, H.; Nara, S.; Kinbara, K.; Aida, T. J. Am. Chem. Soc. 2008, 130 , 6725-6727. (i) Fukino, T.; Fujita, N.; Aida, T. Org. Lett. 2010, 12, 3074-3077. (j) Nakamura, N.; Kagawa, S. Mol. Cryst. Liq. Cryst. Sci. Technol., Sect. A 2011, 549, 150-159. (k) Lim, J. Y. C.; Beer, P. D. Eur. J. Inorg. Chem. 2017, 2017, 220-224.

(6) (a) Bickert, P.; Hildebrandt, B.; Hafner, K. Organometallics 1984, 3, 653-657. (b) Lee, S.-G.; Lee, H.-K.; Lee, S. S.; Chung, Y. K. Organometallics 1997, 16, 304-306. (c) Broussier, R.; Bentabet, E.; Mellet, P.; Blacque, O.; Boyer, P.; Kubicki, M. M.; Gautheron, B. J. Organomet. Chem. 2000, 598, 365-373.

(7) (a) Nagai, Y.; Hooz, J.; Benkeser, R. A. Bull. Chem. Soc. Jpn. 1964, 37, 53-60. (b) Nesmeyanov, A. N.; Leonova, E. V.; Kochetkova, N. S.; Malkova, A. I.; Makarovskaya, A. G. J. Organomet. Chem. 1975, 96, 275-278. (c) Hisatome, M.; Tachikawa, O.; Sasho, M.; Yamakawa, K. J. Organomet. Chem. 1981, 217, C17-C20.

(8) (a) Pichon, C.; Odell, B.; Brown, J. M. Chem. Commun. 2004, 598-599. (b) Datta, A.; Koellhofer, A.; Plenio, H. Chem. Commun. 2004, 1508-1509. (c) Masson, G.; Lough, A. J.; Manners, I. Macromolecules 2008, 41, 539-547.

(9) (a) Clegg, W.; Henderson, K. W.; Kennedy, A. R.; Mulvey, R. E.; O'Hara, C. T.; Rowlings, R. B.; Tooke, D. M. Angew. Chem. Int. Ed. 2001, 40, 3902-3905. (b) Andrikopoulos, P. C.; Armstrong, D. R.; Clegg, W.; Gilfillan, C. J.; Hevia, E.; Kennedy, A. R.; Mulvey, R. E.; O'Hara, C. T.; Parkinson, J. A.; Tooke, D. M. J. Am. Chem. Soc. 2004, 126, 11612-11620. (c) Clegg, W.; Crosbie, E.; Dale-Black, S. 
H.; Hevia, E.; Honeyman, G. W.; Kennedy, A. R.; Mulvey, R. E.; Ramsay, D. L.; Robertson, S. D. Organometallics 2015, 34, 25802589.

(10) Slocum, D. W.; Marchal, R. L.; Jones, W. E. J. Chem. Soc., Chem. Commun. 1974, 967-968.

(11) (a) Butler, I. R.; Horton, P. N.; Fortune, K. M.; Morris, K.; Greenwell, C. H.; Eastham, G. R.; Hursthouse, M. B. Inorg. Chem. Commun. 2004, 7, 923-928. (b) Steurer, M.; Tiedl, K.; Wang, Y.; Weissensteiner, W. Chem. Commun. 2005, 4929-4931. (c) Butler, I. R.; Woldt, B.; Oh, M.-Z.; Williams, D. J. Inorg. Chem. Commun. 2006, 9, 1255-1258. (d) Thomas, D. A.; Ivanov, V. V.; Butler, I. R.; Horton, P. N.; Meunier, P.; Hierso, J. C. Inorg. Chem. 2008, 47, 1607-1615. (e) Steurer, M.; Wang, Y.; Mereiter, K.; Weissensteiner, W. Organometallics 2007, 26, 3850-3859.

(12) (a) D'Antona, N.; Lambusta, D.; Morrone, R.; Nicolosi, G.; Secundo, F. Tetrahedron: Asymmetry 2004, 15, 3835-3840. (b) Ferber, B.; Top, S.; Welter, R.; Jaouen, G. Chem. Eur. J. 2006, 12, 20812086.

(13) (a) Gronowitz, S. Adv. Heterocycl. Chem. 1963, 14, 1-124. (b) Queguiner, G.; Marsais, F.; Snieckus, V.; Epsztajn, J. Adv. Heterocycl. Chem. 1991, 52, 187-304. (c) Fröhlich, J. Prog. Heterocycl. Chem. 1994, 6, 1-35. (d) Schlosser, M. Eur. J. Org. Chem. 2001, 3975-3984. (e) Schlosser, M. Angew. Chem. Int. Ed. 2005, 44, 376393. (f) Duan, X.-F.; Zhang, Z.-B. Heterocycles 2005, 65, 2005-2012. (g) Schlosser, M.; Mongin, F. Chem. Soc. Rev. 2007, 36, 1161-1172. (h) Schnürch, M. Top. Heterocycl. Chem. 2012, 27, 185-218. (i) Erb, W.; Mongin, F. Tetrahedron 2016, 72, 4973-4988.

(14) Dayaker, G.; Sreeshailam, A.; Chevallier, F.; Roisnel, T.; Radha Krishna, P.; Mongin, F. Chem. Commun. 2010, 46, 2862-2864.

(15) (a) L'Helgoual'ch, J. M.; Seggio, A.; Chevallier, F.; Yonehara, M.; Jeanneau, E.; Uchiyama, M.; Mongin, F. J. Org. Chem. 2008, 73, 177-183. (b) García-Álvarez, P.; Mulvey, R. E.; Parkinson, J. A. Angew. Chem. Int. Ed. 2011, 50, 9668-9671.

(16) Zirakzadeh, A.; Herlein, A.; Gross, M. A.; Mereiter, K.; Wang, Y.; Weissensteiner, W. Organometallics 2015, 34, 3820-3832.

(17) (a) Little, W. F.; Eisenthal, R. J. Am. Chem. Soc. 1960, 82, 1577-1580. For more recent papers, see: (b) Hu, J.; Barbour, L. J.; Gokel, G. W. New J. Chem. 2004, 28, 907-911. (c) Lapić, J.; Pezerović, A.; Cetina, M.; Djaković, S.; Rapić, V. J. Mol. Struct. 2011, 990, 209-216.

(18) Recently, lithioferrocenes were reacted with carbamoyl chlorides in order to prepare hybrid ferrocene phosphanes: Fernandes, T. A.; Solařová, H.; Císařová, I.; Uhlík, F.; Štícha, M.; Štěpnička, P. Dalton Trans. 2015, 44, 3092-3108.

(19) Breit, B.; Breuninger, D. Synthesis 2005, 2782-2786.

(20) Kumar, S.; Singh, H. B.; Wolmershäuser, G. Organometallics 2006, 25, 382-393.

(21) Peters, E. M.; Peters, K.; Hinrichs, J.; Bringmann, G. Z. Kristallogr. - New Cryst. Struct. 2001, 216, 221-222.

(22) Metallinos, C. PhD thesis, Queen's University, Kingston, Ontario, Canada, 2001.

(23) Fuentes, M. A.; Kennedy, A. R.; Mulvey, R. E.; Parkinson, J. A.; Rantanen, T.; Robertson, S. D.; Snieckus, V. Chem. Eur. J. 2015, 21, 14812-14822.

(24) Rocca, P.; Cochennec, C.; Marsais, F.; Thomas-dit-Dumont, L.; Mallet, M.; Godard, A.; Queguiner, G. J. Org. Chem. 1993, 58, 7832-7838.

(25) (a) Beak, P.; Meyers, A. I. Acc. Chem. Res. 1986, 19, 356-363. (b) Beak, P.; Kerrick, S. T.; Gallagher, D. J. J. Am. Chem. Soc. 1993, 115, 10628-10636. (c) Whisler, M. C.; MacNeil, S.; Snieckus, V.; Beak, P. Angew. Chem. Int. Ed. 2004, 43, 2206-2225.

(26) (a) Sreeshailam, A.; Dayaker, G.; Ramana, D. V.; Chevallier, F.; Roisnel, T.; Komagawa, S.; Takita, R.; Uchiyama, M.; Radha Krishna, P.; Mongin, F. RSC Adv. 2012, 2, 7030-7032. (b) Ricke, N.; Eustis, S. N.; Bowen, K. H. Int. J. Mass Spectrom. 2014, 357, 63-65. (c) Inkpen, M. S.; Du, S.; Hildebrand, M.; White, A. J. P.; Harrison, N. M.; Albrecht, T.; Long, N. J. Organometallics 2015, 34, 54615469. (d) Chatterjee, T.; Theophall, G. G.; Silva, K. I.; Lakshmi, K. V.; Ravikanth, M. Inorg. Chem. 2016, 55, 6873-6881.
(27) (a) Bourke, J. D.; Islam, M. T.; Best, S. P.; Tran, C. Q.; Wang, F.; Chantler, C. T. J. Phys. Chem. Lett. 2016, 7, 2792-2796. (b) Coriani, S.; Haaland, A.; Helgaker, T.; Jørgensen, P. ChemPhysChem 2006, 7, 245-249.

(28) For ferrocene carboxamides, the barrier of rotation of the carboxamide group around the $\mathrm{C}-\mathrm{C}(\mathrm{O})$ bond was estimated earlier to be about 35-40 kJ/mol: Lin, L.; Berces, A.; Kraatz, H.-B. J. Organomet. Chem. 1998, 556, 11-20.

(29) Concerning the utility amides of LiTMP and LiDA, see: Mulvey, R. E.; Robertson, S. D. Angew. Chem. Int. Ed. 2013, 52, 1147011487.

(30) Fraser, R. R.; Mansour, T. S.; Savard, S. J. Org. Chem. 1985, $50,3232-3234$.

(31) Denisovich, L. I.; Gubin, S. P. J. Organomet. Chem. 1973, 57, 109-119.

(32) (a) Matulis, V. E.; Halauko, Y. S.; Ivashkevich, O. A.; Gaponik, P. N. J. Mol. Struct.: THEOCHEM 2009, 909, 19-24. (b) Kadiyala, R. R.; Tilly, D.; Nagaradja, E.; Roisnel, T.; Matulis, V. E.; Ivashkevich, O. A.; Halauko, Y. S.; Chevallier, F.; Gros, P. C.; Mongin, F. Chem. Eur. J. 2013, 19, 7944-7960.

(33) (a) Clegg, W.; Dale, S. H.; Drummond, A. M.; Hevia, E.; Honeyman, G. W.; Mulvey, R. E. J. Am. Chem. Soc. 2006, 128, 74347435. (b) Clegg, W.; Conway, B.; Hevia, E.; McCall, M. D.; Russo, L.; Mulvey, R. E. J. Am. Chem. Soc. 2009, 131, 2375-2384.

(34) Mongin, F.; Marzi, E.; Schlosser, M. Eur. J. Org. Chem. 2001, 2771-2777.

(35) Wright, S. W.; Hageman, D. L.; McClure, L. D. J. Org. Chem. 1994, 59, 6095-6097.

(36) Dayaker, G.; Sreeshailam, A.; Ramana, D. V.; Chevallier, F.; Roisnel, T.; Komagawa, S.; Takita, R.; Uchiyama, M.; Krishna, P. R.; Mongin, F. Tetrahedron 2014, 70, 2102-2117.

(37) Gottlieb, H. E.; Kotlyar, V.; Nudelman, A. J. Org. Chem. 1997, 62, 7512-7515.

(38) Sheldrick, G. M. Acta Crystallogr., Sect. A 2015, 71, 3-8.

(39) Sheldrick, G. M. Acta Crystallogr., Sect. C 2015, 71, 3-8.

(40) Farrugia, L. J. J. Appl. Crystallogr. 1997, 30, 565.

(41) Sanders, R.; Mueller-Westerhoff, U. T. J. Organomet. Chem. 1996, 512, 219-224.

(42) Kjonaas, R. A.; Hoffer, R. K. J. Org. Chem. 1988, 53, 41334135 .

(43) O'Brien, M.; Denton, R.; Ley, S. V. Synthesis 2011, 11571192.

(44) Frisch, M. J.; Trucks, G. W.; Schlegel, H. B.; Scuseria, G. E.; Robb, M. A.; Cheeseman, J. R.; Scalmani, G.; Barone, V.; Mennucci, B.; Petersson, G. A.; Nakatsuji, H.; Caricato, M.; Li, X.; Hratchian, H. P.; Izmaylov, A. F.; Bloino, J.; Zheng, G.; Sonnenberg, J. L.; Hada, M.; Ehara, M.; Toyota, K.; Fukuda, R.; Hasegawa, J.; Ishida, M.; Nakajima, T.; Honda, Y.; Kitao, O.; Nakai, H.; Vreven, T.; Montgomery, J., J. A.; Peralta, J. E.; Ogliaro, F.; Bearpark, M.; Heyd, J. J.; Brothers, E.; Kudin, K. N.; Staroverov, V. N.; Kobayashi, R.; Normand, J.; Raghavachari, K.; Rendell, A.; Burant, J. C.; Iyengar, S. S.; Tomasi, J.; Cossi, M.; Rega, N.; Millam, J. M.; Klene, M.; Knox, J. E.; Cross, J. B.; Bakken, V.; Adamo, C.; Jaramillo, J.; Gomperts, R.; Stratmann, R. E.; Yazyev, O.; Austin, A. J.; Cammi, R.; Pomelli, C.; Ochterski, J. W.; Martin, R. L.; Morokuma, K.; Zakrzewski, V. G.; Voth, G. A.; Salvador, P.; Dannenberg, J. J.; Dapprich, S.; Daniels, A. D.; Farkas, Ö.; Foresman, J. B.; Ortiz, J. V.; Cioslowski, J.; Fox, D. J., Gaussian 09, Revision A.02, Gaussian Inc., Wallingford, CT, 2009.

(45) Becke, A. D. J. Chem. Phys. 1993, 98, 5648-5652.

(46) Cances, E.; Mennucci, B.; Tomasi, J. J. Chem. Phys. 1997, 107, 3032-3041.

(47) Nagaradja, E.; Chevallier, F.; Roisnel, T.; Dorcet, V.; Halauko, Y. S.; Ivashkevich, O. A.; Matulis, V. E.; Mongin, F. Org. Biomol. Chem. 2014, 1475-1487.

(48) Yanai, T.; Tew, D. P.; Handy, N. C. Chem. Phys. Lett. 2004, $393,51-57$ 


$$
\text { (53\% yield) }
$$

